\title{
Impacts of meteorology and emissions on summertime surface ozone increases over central eastern China between 2003 and 2015
}

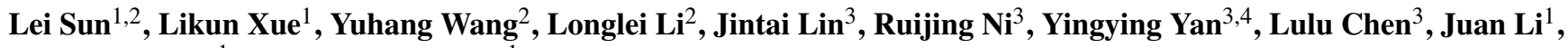 \\ Qingzhu Zhang ${ }^{1}$, and Wenxing Wang ${ }^{1}$ \\ ${ }^{1}$ Environment Research Institute, Shandong University, Ji'nan, Shandong, China \\ ${ }^{2}$ School of Earth and Atmospheric Sciences, Georgia Institute of Technology, Atlanta, GA, USA \\ ${ }^{3}$ Laboratory for Climate and Ocean-Atmosphere Studies, Department of Atmospheric and Oceanic Sciences, \\ School of Physics, Peking University, Beijing, China \\ ${ }^{4}$ Department of Atmospheric Sciences, School of Environmental Studies, China University of Geosciences (Wuhan), \\ 430074, Wuhan, China
}

Correspondence: Likun Xue (xuelikun@sdu.edu.cn) and Yuhang Wang (yuhang.wang@eas.gatech.edu)

Received: 18 July 2018 - Discussion started: 24 July 2018

Revised: 28 November 2018 - Accepted: 23 January 2019 - Published: 4 February 2019

\begin{abstract}
Recent studies have shown that surface ozone $\left(\mathrm{O}_{3}\right)$ concentrations over central eastern China (CEC) have increased significantly during the past decade. We quantified the effects of changes in meteorological conditions and $\mathrm{O}_{3}$ precursor emissions on surface $\mathrm{O}_{3}$ levels over CEC between July 2003 and July 2015 using the GEOS-Chem model. The simulated monthly mean maximum daily $8 \mathrm{~h}$ average $\mathrm{O}_{3}$ concentration (MDA8 $\mathrm{O}_{3}$ ) in July increased by approximately $13.6 \%$, from $65.5 \pm 7.9 \mathrm{ppbv}$ (2003) to $74.4 \pm 8.7 \mathrm{ppbv}$ (2015), comparable to the observed results. The change in meteorology led to an increase in MDA8 $\mathrm{O}_{3}$ of $5.8 \pm 3.9 \mathrm{ppbv}$ over the central part of CEC, in contrast to a decrease of about $-0.8 \pm 3.5 \mathrm{ppbv}$ over the eastern part of the region. In comparison, the MDA8 $\mathrm{O}_{3}$ over the central and eastern parts of CEC increased by $3.5 \pm 1.4$ and $5.6 \pm 1.8 \mathrm{ppbv}$ due to the increased emissions. The increase in averaged $\mathrm{O}_{3}$ in the CEC region resulting from the emission increase $(4.0 \pm 1.9 \mathrm{ppbv})$ was higher than that caused by meteorological changes $(3.1 \pm 4.9 \mathrm{ppbv})$ relative to the 2003 standard simulation, while the regions with larger $\mathrm{O}_{3}$ increases showed a higher sensitivity to meteorological conditions than to emission changes. Sensitivity tests indicate that increased levels of anthropogenic non-methane volatile organic compounds (NMVOCs) dominate the $\mathrm{O}_{3}$ increase over the eastern part of CEC, and anthropogenic nitrogen oxides $\left(\mathrm{NO}_{x}\right)$ mainly increase MDA8 $\mathrm{O}_{3}$ over the central and western parts and decrease $\mathrm{O}_{3}$ in a few urban areas in the
\end{abstract}

eastern part. Budget analysis showed that net photochemical production and meteorological conditions (transport in particular) are two important factors that influence $\mathrm{O}_{3}$ levels over the CEC. The results of this study suggest a need to further assess the effectiveness of control strategies for $\mathrm{O}_{3}$ pollution in the context of regional meteorology and anthropogenic emission changes.

\section{Introduction}

Tropospheric ozone $\left(\mathrm{O}_{3}\right)$ is a major atmospheric oxidant and the primary source of hydroxyl radicals $(\mathrm{OH})$, which control the atmospheric oxidizing capacity (Seinfeld and Pandis, 2016). In the troposphere, $\mathrm{O}_{3}$ is produced by the photochemical oxidation of hydrocarbons, carbon monoxide $(\mathrm{CO})$ and nitrogen oxides $\left(\mathrm{NO}_{x}\right)$ in the presence of sunlight and can be transported from the stratosphere (Crutzen, 1973; Danielsen, 1968). It is an important greenhouse gas with a positive radiative forcing of $0.4(0.2-0.6) \mathrm{W} \mathrm{m}^{-2}$ (IPCC, 2013), and it has adverse effects on human health and ecosystem productivity (Monks et al., 2015).

Surface $\mathrm{O}_{3}$ concentrations increased globally during the 20th century. Almost all available monitoring data from 1950-1979 until 2000-2010 for the Northern Hemisphere indicate an increase of 1-5 ppbv per decade (Cooper et al., 2014; Gaudel et al., 2018; Monks et al., 2015), although 
the trends have varied regionally since the 1990s. The $\mathrm{O}_{3}$ concentrations in rural and remote areas of Europe showed an increasing trend until 2000, but then tended to level off or decline (Oltmans et al., 2013; Parrish et al., 2014; Yan et al., 2018b). In the eastern US, summertime $\mathrm{O}_{3}$ has continued declining since 1990 , whereas springtime $\mathrm{O}_{3}$ in the western US shows large interannual variability (Lin et al., 2015). At some remote sites in the western US, only small increases $\left(0.00-0.43 \mathrm{ppbv} \mathrm{yr}^{-1}\right)$ have been recorded (Cooper et al., 2012). In comparison with Europe and North America, the $\mathrm{O}_{3}$ concentrations in China have shown significant increasing trends since the 1990s (Ding et al., 2008; Ma et al., 2016, Sun et al., 2016; X. Xu et al., 2008; W. Xu et al., 2016, 2018). Ding et al. (2008) reported an increase of $3 \mathrm{ppbv} \mathrm{yr}^{-1}$ in the afternoon boundary-layer $\mathrm{O}_{3}$ concentrations in summer over Beijing using aircraft data obtained by the Measurement of Ozone and Water Vapor by Airbus In-Service Aircraft (MOZAIC) program during 1995-2005. The maximum daily $8 \mathrm{~h}$ average $\mathrm{O}_{3}$ concentration (MDA8 $\mathrm{O}_{3}$ ) at Shangdianzi (SDZ), a rural site near Beijing, showed a significant increase at a rate of about $1.1 \mathrm{ppbv} \mathrm{yr}^{-1}$ from 2003 to 2015 (Ma et al., 2016). Sun et al. (2016) reported an increase of $1.7-2.1 \mathrm{ppbv} \mathrm{yr}^{-1}$ at Mt. Tai during summertime from 2003 to 2015. In recent years, high $\mathrm{O}_{3}$ concentrations have been widely observed in China, especially in central eastern China (CEC: 103 to $120^{\circ} \mathrm{E}, 28$ to $40^{\circ} \mathrm{N}$ ) during the summertime (Lu et al., 2018; Wang et al., 2006, 2017; Xue et al., 2014). All of these results indicate that CEC might continue to experience worsening $\mathrm{O}_{3}$ air pollution. In this study, we quantify the effects of several factors on $\mathrm{O}_{3}$ changes and propose some suggestions to control surface $\mathrm{O}_{3}$ in the future.

The level of $\mathrm{O}_{3}$ in the troposphere is mainly determined by the abundance of its precursors, including both anthropogenic and natural emissions, and the meteorological conditions (Logan, 1985). The anthropogenic $\mathrm{NO}_{x}$ emissions in China continued rising until the launch of the Twelfth FiveYear Plan (2011-2015), which enforced a series of stringent $\mathrm{NO}_{x}$ emission control measures (China State Council, 2011). However, anthropogenic emissions of non-methane volatile organic compounds (NMVOCs) continue to increase unabated (Li et al., 2017a; Zheng et al., 2018). Biomass burning also makes an important contribution to $\mathrm{O}_{3}$ formation (Real et al., 2007; Yamaji et al., 2010), and biogenic emissions of isoprene and monoterpenes contribute to $\mathrm{O}_{3}$ levels, which are influenced by meteorological variations ( $\mathrm{Fu}$ and Liao, 2012). Meteorological parameters, such as wind, temperature and humidity, can influence $\mathrm{O}_{3}$ concentrations via mechanisms related to transport, chemical production and loss, and deposition (Monks, 2000; Zhao et al., 2010). Studies in the past 2 decades have shown that $\mathrm{O}_{3}$ and its precursors can be transported across regions and even hemispheres, as it has a lifetime of several days to weeks in the troposphere (Jacob et al., 1999; Lin et al., 2008; Verstraeten et al., 2015). For example, Ni et al. (2018) showed significant foreign contributions to springtime $\mathrm{O}_{3}$ over China. In addition, the stratosphere-troposphere exchange (STE) is another important process affecting the tropospheric $\mathrm{O}_{3}$ burden, especially in the midlatitudes of the Northern Hemisphere during springtime (Hess and Zbinden, 2013). However, currently there is still large variation in quantifying the contribution of each factor to the $\mathrm{O}_{3}$ trends among different models and study regions (Zhang et al., 2014a).

Previous studies have revealed the important effects of changing emission levels and varying climate conditions on tropospheric $\mathrm{O}_{3}$ in different regions. Lou et al. (2015) found that the effect of variations in meteorological conditions on the interannual variability in surface $\mathrm{O}_{3}$ was larger than that of variations in anthropogenic emissions in eastern China from 2004 to 2012. Using the GEOS-Chem model, Yan et al. (2018a) found that interannual climate variability is the main driver of daytime $\mathrm{O}_{3}$ variability in the US, although the reduction of anthropogenic emissions of $\mathrm{NO}_{x}$ increased the nighttime $\mathrm{O}_{3}$ concentrations due to reduced $\mathrm{O}_{3}$ titration. The effects of the East Asian summer monsoon on surface $\mathrm{O}_{3}$ have been analyzed by observational and modeling studies (He et al., 2008; Wang et al., 2011; Zhao et al., 2010). Given the scarcity of previous research, it is necessary to further quantify the contributions of emissions and meteorological conditions to surface $\mathrm{O}_{3}$ levels to deepen our understanding of the factors influencing $\mathrm{O}_{3}$ changes in China.

This is a follow-up study of Sun et al. (2016), who found a significant increase in summertime $\mathrm{O}_{3}$ at a regional site in north China from 2003 and 2015. We integrate the global GEOS-Chem model and its Asian nested model to investigate the spatial distributions of surface $\mathrm{O}_{3}$ over the whole CEC region and to quantify the relative contributions from changes in meteorological and anthropogenic emissions between 2003 and 2015. We identify the key factors that affect $\mathrm{O}_{3}$ changes and make a policy recommendation for $\mathrm{O}_{3}$ control in CEC in the future. Section 2 briefly introduces the GEOS-Chem model and simulation scenarios. Comparisons of the simulated and observed $\mathrm{O}_{3}$ concentrations are made in Sect. 3. We quantify the individual effects of meteorological conditions and emissions on $\mathrm{O}_{3}$ changes in Sects. 4 and 5, respectively. In Sect. 6, we discuss important processes influencing $\mathrm{O}_{3}$ changes. Section 7 concludes the paper.

\section{Model and simulations}

\subsection{Model description}

A nested model coupled with the global chemical transport model GEOS-Chem v11-01 (http://wiki.seas.harvard. edu/geos-chem/index.php/GEOS-Chem_v11-01\T1 textbackslash\#v11-01_public_release, last access: 30 September 2018) is used to simulate the surface $\mathrm{O}_{3}$ concentrations and distributions over CEC in July of 2003 and 2015. The meteorological field is taken from MERRA-2 as assimilated by the Goddard Earth Observing System 
(GEOS) at NASA's Global Modeling and Assimilation Office. The global model and its nested model, covering China and Southeast Asia (60 to $150^{\circ} \mathrm{E}, 11^{\circ} \mathrm{S}$ to $55^{\circ} \mathrm{N}$ ), are configured to have horizontal spatial resolutions of $2^{\circ} \times 2.5^{\circ}$ and $0.5^{\circ} \times 0.625^{\circ}$, respectively, by latitude and longitude, and 47-layer reduced grids in the vertical direction with 10 layers (each $\sim 130 \mathrm{~m}$ in thickness) below $850 \mathrm{hPa}$. The models are run with the full standard $\mathrm{NO}_{x}-$ $\mathrm{O}_{x}$-hydrocarbon-aerosol tropospheric chemistry (Mao et al., 2013) for January to August of 2003 and 2015, including the spin-up time of 6 months (January to June) for each simulation, but only the results for July are discussed in this paper. The results of August 2003 and 2015 are discussed in the Supplement to confirm the result of this study. Since the crop residue burning usually lasts from late May to late June over CEC and the emissions had varied greatly over the past decade, which introduces large uncertainty in the evaluation of impacts from anthropogenic emissions (Chen et al., 2017; Wu et al., 2018), we do not focus on the $\mathrm{O}_{3}$ change simulations in June. For comparison, we also conducted model simulations for July 2004 and July 2014, and the results supported the major findings obtained from 2003 and 2015 (see results in the Supplement). We use the Linoz stratospheric ozone chemistry mechanism for stratospheric $\mathrm{O}_{3}$ production (McLinden et al., 2000) and the nonlocal planetary boundary layer (PBL) mixing scheme for vertical mixing of air tracers in the PBL (Holtslag and Boville, 1993; Lin and McElroy, 2010).

Global anthropogenic emissions of $\mathrm{NO}_{x}$ and $\mathrm{CO}$ for 2003 and 2008 are taken from EDGAR v4.2 (Emission Database for Global Atmospheric Research, http://edgar.jrc.ec.europa. eu/overview.php?v=42, last access: 5 June 2018). NMVOC emissions are taken from the RETRO (REanalysis of TROpospheric chemical composition) inventory for 2000, but the emissions of $\mathrm{C}_{2} \mathrm{H}_{6}$ and $\mathrm{C}_{3} \mathrm{H}_{8}$ follow Xiao et al. (2008). For Europe, the US, Asia, China, Canada and Mexico, the anthropogenic emissions are taken from EMEP (from 2003 to 2012; Auvray et al., 2005), NEI2011 (base year: 2011; annual scale factors: 2006-2013; ftp://aftp.fsl.noaa.gov/divisions/ taq/, last access: 5 June 2018), MIX (from 2008 to 2010; Li et al., 2017b), MEIC (2008 and 2014; http://meicmodel.org, last access: 6 June 2018), CAC ( $\mathrm{NO}_{x}$ and CO: from 2003 to 2008 (scaled to 2010); http://www.ec.gc.ca/pdb/cac/cac_ home_e.cfm, last access: 2 October 2018), and BRAVO (1999; Kuhns et al., 2003), respectively. Over China, the $\mathrm{CO}, \mathrm{NO}_{x}$ and NMVOC emissions from MEIC for 2008 are scaled to 2003 based on the interannual variability in Regional Emission inventory in ASia (REAS-v2; Kurokawa et al., 2013), but the anthropogenic emissions for 2014 are taken directly without being scaled to 2015. According to Zheng et al. (2018), the anthropogenic $\mathrm{NO}_{x}$ and NMVOC emissions in China decreased by about $6 \%$ and $2 \%$ from 2014 to 2015 , respectively, so here we may slightly overestimate the $\mathrm{NO}_{x}$ and NMVOC emissions. Daily biomass burning emissions are taken from the Global Fire Emission
Database v4 (GFED4) (Randerson et al., 2012). Biogenic emissions in the GEOS-Chem model are calculated online from the MEGAN v2.1 scheme (Guenther et al., 2012). Natural $\mathrm{NO}_{x}$ emissions from lightning are parameterized following Price and Rind (1992) and are further constrained by the LIS/OTD satellite data (Murray et al., 2012). We obtain the vertical profile of the lightning $\mathrm{NO}_{x}$ based on Ott et al. (2010) and calculate the soil $\mathrm{NO}_{x}$ emissions online following Hudman et al. (2012).

\subsection{Model simulations}

Table 1 summarizes the six model scenarios we set to identify the contributions from the changes in meteorological conditions and emissions between 2003 and 2015. We refer to the scenario using the emissions described in the previous section as the standard simulation and define the standard simulations for 2003 and 2015 as 03E03M and 15E15M (2003 emissions + 2003 meteorology and 2015 emissions +2015 meteorology). In this case, the difference between $\mathrm{O}_{3}$ concentrations for $03 \mathrm{E} 03 \mathrm{M}$ and $15 \mathrm{E} 15 \mathrm{M}$ (denoted as $15 \mathrm{E} 15 \mathrm{M}-03 \mathrm{E} 03 \mathrm{M}$ ) is due to the combined effect of changes in emissions and meteorology between 2003 and 2015. Similarly, scenarios with 2003 emissions + 2015 meteorology and 2015 emissions + 2003 meteorology are defined as $03 \mathrm{E} 15 \mathrm{M}$ and $15 \mathrm{E} 03 \mathrm{M}$, respectively. The contribution of the change in meteorological conditions can thus be calculated by the difference between the simulated $\mathrm{O}_{3}$ concentrations in the $03 \mathrm{E} 15 \mathrm{M}$ and $03 \mathrm{E} 03 \mathrm{M}$ scenarios (03E15M - 03E03M). Similarly, the contribution of emission changes can be calculated by $15 \mathrm{E} 03 \mathrm{M}-03 \mathrm{E} 03 \mathrm{M}$ (or $15 \mathrm{E} 15 \mathrm{M}-03 \mathrm{E} 15 \mathrm{M})$. The contribution of the meteorological change based on the 2015 standard simulation is given by $15 \mathrm{E} 15 \mathrm{M}-15 \mathrm{E} 03 \mathrm{M}$. Since the amount of $\mathrm{O}_{3}$ formed responds nonlinearly to the $\mathrm{NO}_{x}$ and NMVOC emissions, the sum of $(03 \mathrm{E} 15 \mathrm{M}-03 \mathrm{E} 03 \mathrm{M})$ and $(15 \mathrm{E} 03 \mathrm{M}-03 \mathrm{E} 03 \mathrm{M})$ does not equal (15E15M - 03E03M). However, we can still compare these two scenarios to quantify the effects of meteorology and emission changes.

We then investigate the effect of anthropogenic emissions $\left(\mathrm{NO}_{x}\right.$ and NMVOCs) on surface $\mathrm{O}_{3}$ concentrations based on the 2015 simulations. We replace the anthropogenic $\mathrm{NO}_{x}$ or NMVOC emissions in the 2015 standard simulation with corresponding emissions for 2003 and keep the meteorology field, biomass burning and natural emissions $\left(\mathrm{NO}_{x}\right.$ from soil and lightning, biogenic VOCs (BVOCs), etc.) unchanged (03N15M and 03V15M, respectively). The contributions of anthropogenic $\mathrm{NO}_{x}$ and NMVOC emission changes can be calculated by the differences between 15E15M (the 2015 standard simulation) and 03N15M (the $2003 \mathrm{NO}_{x}$ emission simulation) and between 15E15M and 03V15M (the 2003 NMVOC emission simulation), respectively. 
Table 1. Model simulation scenarios in this study.

\begin{tabular}{ll}
\hline Name & Description \\
\hline $\begin{array}{l}\text { 1. } 2003 \text { standard } \\
(03 \mathrm{E} 03 \mathrm{M})\end{array}$ & $\begin{array}{l}\text { The standard simulation of } \mathrm{O}_{3} \text { concentrations over China based on } 2003 \\
\text { emissions and } 2003 \text { meteorology }\end{array}$ \\
$\begin{array}{l}\text { 2. } 2015 \text { standard } \\
(15 \mathrm{E} 15 \mathrm{M})\end{array}$ & $\begin{array}{l}\text { The standard simulation of } \mathrm{O}_{3} \text { concentrations over China based on } 2015 \\
\text { emissions and } 2015 \text { meteorology }\end{array}$ \\
$3.03 \mathrm{E} 15 \mathrm{M}$ & Same as 2 but with 2003 emissions \\
4. $15 \mathrm{E} 03 \mathrm{M}$ & Same as 2 but with 2003 meteorology \\
$5.03 \mathrm{~N} 15 \mathrm{M}$ & Same as 2 but with 2003 anthropogenic $\mathrm{NO}_{x}$ emissions in China \\
$6.03 \mathrm{~V} 15 \mathrm{M}$ & Same as 2 but with 2003 anthropogenic $\mathrm{NMVC}^{\mathrm{m}}$ emissions in China \\
\hline
\end{tabular}

\section{Simulated and observed $\mathrm{O}_{3}$ concentrations}

\subsection{Model evaluation}

In this section, we evaluate the model's performance by comparing the simulated surface $\mathrm{O}_{3}$ concentrations with observations from baseline sites and the network of the Chinese National Environmental Monitoring Center (http: //datacenter.mee.gov.cn/aqiweb2/getAirQualityDailyEn, last access: 2 October 2018 (in English) and http://datacenter. mee.gov.cn/websjzx/queryIndex.vm, last access: 2 October 2018 (in Chinese)).

For 2003 and 2004, only a few nonurban sites over CEC have surface $\mathrm{O}_{3}$ measurements available. We selected six rural/baseline sites for the model evaluation: Mt. Tai $\left(36.25^{\circ} \mathrm{N}, 117.10^{\circ} \mathrm{E} ; 1534 \mathrm{~m}\right.$ a.s.1.), Mt. Hua $\left(34.49^{\circ} \mathrm{N}\right.$, $110.09^{\circ} \mathrm{E} ; 2064 \mathrm{~m}$ a.s.l.), Mt. Huang $\left(30.13^{\circ} \mathrm{N}, 118.15^{\circ} \mathrm{E}\right.$; $1840 \mathrm{~m}$ a.s.l.), $\mathrm{SDZ}\left(40.65^{\circ} \mathrm{N}, 117.12^{\circ} \mathrm{E} ; 293 \mathrm{~m}\right.$ a.s.l. $)$, Lin'an $\left(30.30^{\circ} \mathrm{N}, 119.73^{\circ} \mathrm{E} ; 139 \mathrm{ma.s.l}\right)$, and Cape D'Aguilar $\left(22.22^{\circ} \mathrm{N}, 114.25^{\circ} \mathrm{E}\right.$; $60 \mathrm{~m}$ a.s.l.) (see Fig. S1 for the locations of these sites). The monthly mean $\mathrm{O}_{3}$ concentrations at these six sites were taken from the literature (Li et al., 2007; Meng et al., 2009; Wang et al., 2009; Fan et al., 2013; Sun et al., 2016). We compare the simulated surface $\mathrm{O}_{3}$ concentrations with the 2003 observations for Mt. Tai and Cape D'Aguilar but with the 2004 observations for the other four sites (Fig. 1a). The simulated surface $\mathrm{O}_{3}$ in 2004 was also compared against these observations in Fig. S2.

Figure 1a compares the observed and simulated monthly mean $\mathrm{O}_{3}$ concentrations at the six sites. The simulated $\mathrm{O}_{3}$ concentrations match the observations at Mt. Tai, SDZ, and Mt. Hua well, with only minor positive biases (1-4 ppbv). In contrast, the model overestimates the $\mathrm{O}_{3}$ concentrations at Mt. Huang, Lin'an, and Cape D'Aguilar by approximately $10 \mathrm{ppbv}$. These sites in the south sector are often rainy or cloudy during summer, so the overestimation of $\mathrm{O}_{3}$ is likely to be due to the model's underestimation of precipitation and cloud cover (Ni et al., 2018). The overestimation at the Cape D'Aguilar coastal site of Hong Kong also reflects that the model resolution is insufficient to capture the local terrains and transport pathway (Ni et al., 2018). Similar results were obtained from the comparison between observed and simu- lated monthly mean $\mathrm{O}_{3}$ concentrations at the six sites in July 2004 (see Fig. S2).

For 2015, the simulated $\mathrm{O}_{3}$ concentrations are compared with observations by the network of the Chinese National Environmental Monitoring Center over east China (Fig. 1b). To avoid the influence of local emission and photochemical and deposition processes on small scales in urban areas, we selected one nonurban site to represent the $\mathrm{O}_{3}$ concentrations of each city over CEC. In general, the selected nonurban sites are suburban or rural sites, which are far away from the urban and industrialized areas. For cities where no nonurban sites are available, we chose the stations that are least affected by local pollution (i.e., sites relatively far away from traffic roads, factories, power plants). As a result, 115 nonurban sites were selected to represent 115 cities in east China. For MDA8 $\mathrm{O}_{3}$, the model results are highly correlated with the observations at most sites $\left(R^{2}=0.79\right)$. The model only overestimates the monthly MDA8 $\mathrm{O}_{3}$ by approximately $2.7 \pm 5.9$ ppbv over CEC.

The model also captures the spatial distribution of MDA8 $\mathrm{O}_{3}$ very well. It ranges from $40-60 \mathrm{ppbv}$ in the south to 80 $100 \mathrm{ppbv}$ in the north of CEC (Fig. 2b), patterns similar to those reported by Lin et al. (2009) and Lou et al. (2015). Time series and diurnal variations in hourly $\mathrm{O}_{3}$ concentrations from the model and observations at Mt. Tai in 2003 and nine representative sites in 2015 are compared in Figs. S3, S4 and S5. The nine observation sites are carefully selected to be far away from urban areas in the capital cities of nine provinces and municipalities, including Beijing, Tianjin, Ji'nan, Taiyuan, Zhengzhou, Wuhan, Chongqing, Changsha and Nanjing. The model reproduces the time series of $\mathrm{O}_{3}$ with a normalized mean bias of $4 \%$ at Mt. Tai. The overestimation of $\mathrm{O}_{3}$ concentrations in the afternoon is likely to be due to the overestimated precursor emissions in the model. For the nine sites, the model captures most day-today variability and diurnal variations (Figs. S4 and S5). However, it produces larger biases during the night, mostly due to the titration of $\mathrm{NO}$ and a lower inversion layer (Yan et al., 2018a). We also compared the simulated diurnal variations in $\mathrm{CO}$ and $\mathrm{NO}_{2}$ in the nine cities against the observational data (see Figs. S6 and S7). Overall, the model captures most 

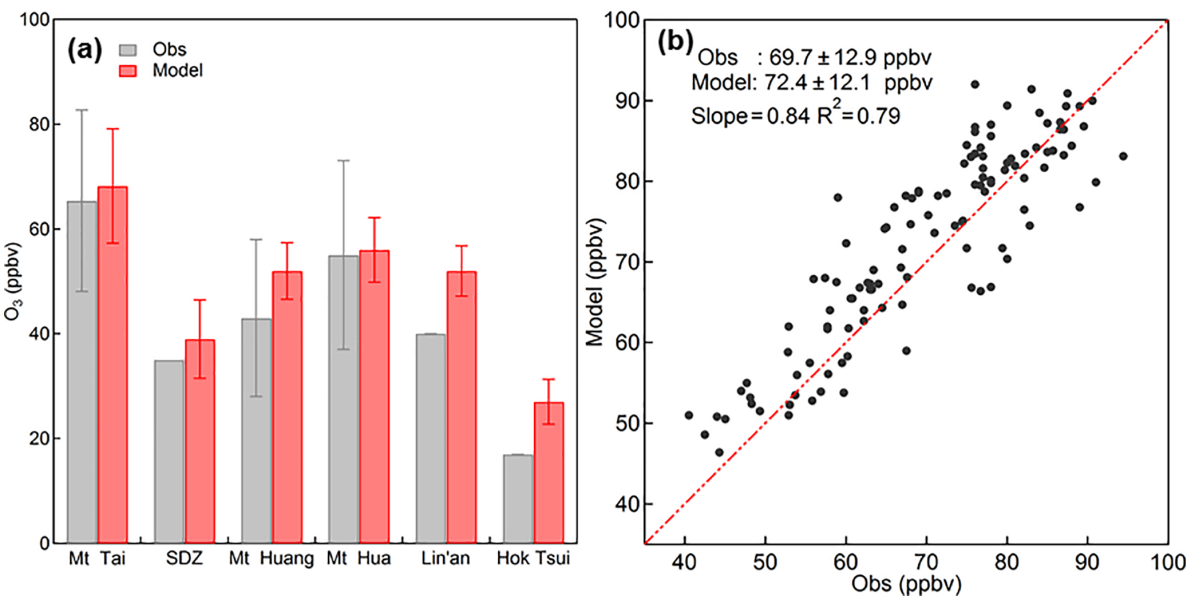

Figure 1. (a) Comparison of observed and simulated monthly mean concentrations of surface $\mathrm{O}_{3}$ in July 2003. (Mt. Tai: July 2003; SDZ: Shangdianzi station: July 2004; Mt. Huang: July 2004; Mt. Hua: July 2004; Lin'an: July 2004; Cape D’Aguilar (or Hok Tsui in a): July 2003). (b) Correlation between observed and modeled monthly mean MDA8 $\mathrm{O}_{3}$ in July 2015 at 115 stations in eastern China.
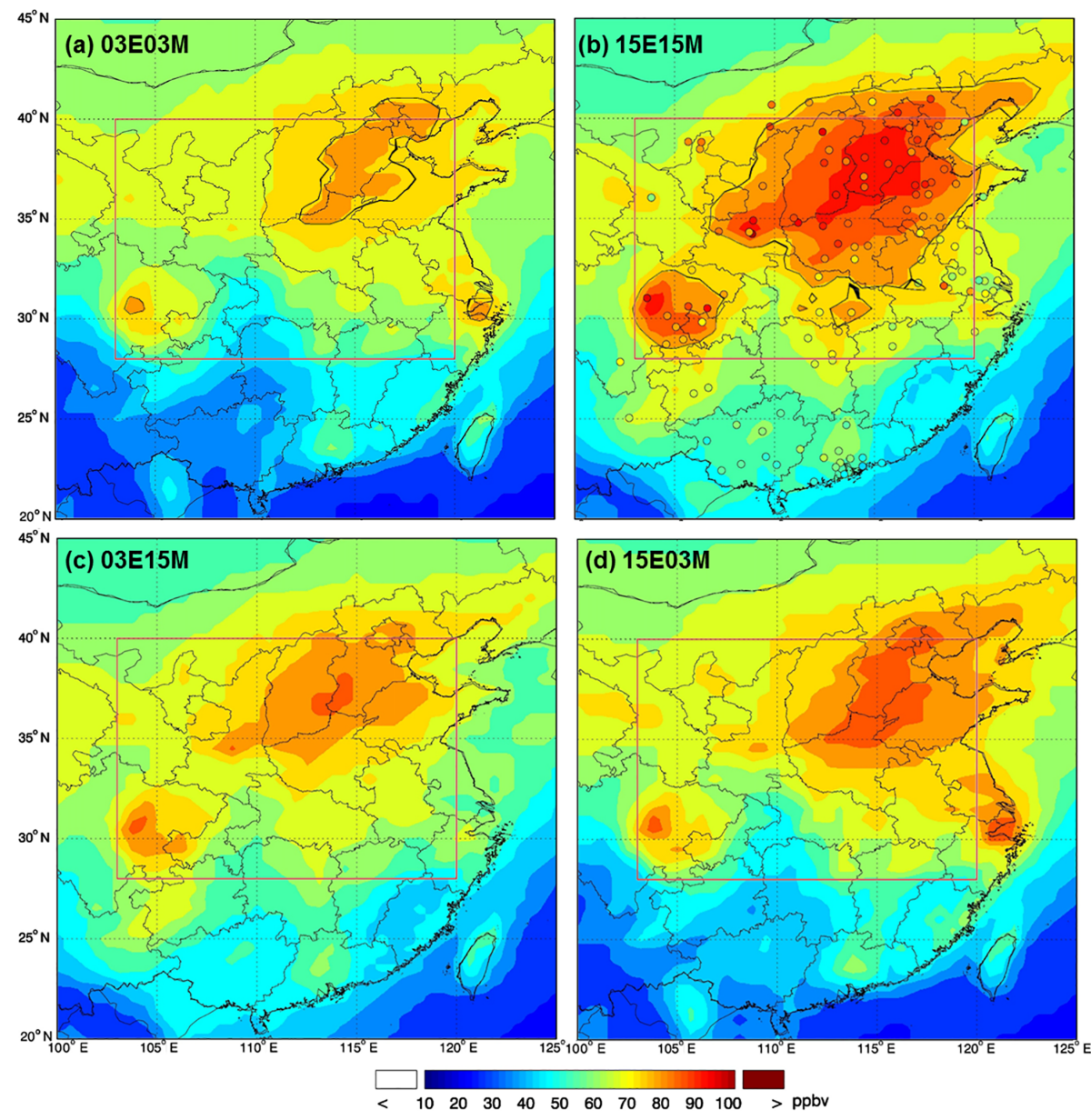

Figure 2. Monthly mean spatial distributions of surface MDA8 $\mathrm{O}_{3}$ in July over east China. (a) 03E03M: 2003 standard simulation; (b) 15E15M: 2015 standard simulation; (c) 03E15M: 2003 emission + 2015 meteorology; (d) 15E03M: 2015 emission + 2003 meteorology. Black contours in (a) and (b) indicate the regions with $\mathrm{MDA}_{8} \mathrm{O}_{3}>75$ ppbv. Filled circles in (b) show the observed MDA8 $\mathrm{O}_{3}$ at 115 sites of the network of the Chinese National Environmental Monitoring Center. The red rectangle represents the central eastern China region (CEC: $\left.103-120^{\circ} \mathrm{E}, 28-40^{\circ} \mathrm{N}\right)$. 
diurnal variations in $\mathrm{CO}$ and $\mathrm{NO}_{2}$. The underestimation of $\mathrm{CO}$ by the model may be due to the underestimation of emissions and/or the excessive OH (Yan et al., 2014; Young et al., 2013). The large bias in $\mathrm{NO}_{2}$ may be due to the effect of local emissions. Another reason for the discrepancy between observed and modeled $\mathrm{NO}_{2}$ is the overestimation by the measurements based on catalytic conversion of other oxidized nitrogen species to NO (Xu et al., 2013).

The observed yearly average MDA8 $\mathrm{O}_{3}$ at SDZ station increased by about 10.9 ppbv from 2004 to 2014 (Ma et al., 2016), comparable to the simulated result, which showed an increase of about 9.5 ppbv from July 2003 to July 2015 . In addition, the observed results of Sun et al. (2016) reported the $\mathrm{MDA}_{8} \mathrm{O}_{3}$ at Mt. Tai increased from $75.9 \pm 15.9$ to $102.1 \pm 28.1 \mathrm{ppbv}$ in July-August from 2003 to 2015, which is higher than the simulated result in this study (i.e., from $71.1 \pm 10.0 \mathrm{ppbv}$ in July 2003 to $90.4 \pm 18.5 \mathrm{ppbv}$ in July 2015). Nonetheless, the model captures the significant increase in surface $\mathrm{O}_{3}$ levels over CEC between July 2003 and July 2015.

\subsection{Spatial distribution and diurnal variation simulated in different model scenarios}

Figure 2 shows the simulated spatial distribution of monthly mean surface MDA8 $\mathrm{O}_{3}$ over eastern China (100 to $125^{\circ} \mathrm{E}$, 20 to $50^{\circ} \mathrm{N}$ ) for July 2003 and July 2015. The model simulates relatively high $\mathrm{O}_{3}$ concentrations over the North China Plain and Sichuan Basin, where anthropogenic emissions of $\mathrm{O}_{3}$ precursors are high. In July 2003, only a small area in CEC had an MDA8 $\mathrm{O}_{3}$ exceeding the Level II National Ambient Air Quality Standard (75 ppbv) (Fig. 2a), but in July 2015 it had expanded to nearly half of this region. Table 2 shows the monthly mean MDA8 $\mathrm{O}_{3}$ over CEC. The regional mean $\mathrm{MDA} 8 \mathrm{O}_{3}$ increased from $65.5 \pm 7.9$ ppbv in July 2003 to $74.4 \pm 8.7 \mathrm{ppbv}$ in July 2015 , showing an increase of about $8.9 \pm 3.9 \mathrm{ppbv}$ in 12 years. According to the limited reports of observed long-term ( $>10$ years) changes of $\mathrm{O}_{3}$ concentrations, we find significant increases in summertime $\mathrm{O}_{3}(1-$ $3 \mathrm{ppbv} \mathrm{yr}^{-1}$ ) in the north part (Beijing), east part (Mt. Tai) and south part (Lin'an) of CEC over the past 2 decades (Ding et al., 2008; Ma et al., 2016; Sun et al., 2016; Xu et al., 2008; Zhang et al., 2014b). Our results show that both daily mean $\mathrm{O}_{3}$ concentration and MDA8 $\mathrm{O}_{3}$ were significantly higher in July 2015 than in July 2003 over most areas of CEC (Fig. 3). The spatial distributions of MDA8 $\mathrm{O}_{3}$ in July 2004 and 2014 in Fig. S8 present patterns similar to in July 2003 and 2015. The regional mean MDA8 $\mathrm{O}_{3}$ increased from $67.8 \pm 6.2 \mathrm{ppbv}$ in July 2004 to $74.8 \pm 9.8 \mathrm{ppbv}$ in July 2014. In addition, the regional mean MDA8 $\mathrm{O}_{3}$ increased from $63.4 \pm 4.9 \mathrm{ppbv}$ in August 2003 to $73.8 \pm 5.0 \mathrm{ppbv}$ in August 2015 (Fig. S9). These results are comparable to those derived from the comparison between July 2003 and July 2015. A detailed description is provided in the Supplement. As the MDA8 $\mathrm{O}_{3}$ over southwestern China did not exceed the Level II National Am- bient Air Quality Standard in July 2015, we do not focus our analysis on this area in the following sections.

The diurnal variation in $\mathrm{O}_{3}$ over CEC illustrated in Fig. 4 shows that $\mathrm{O}_{3}$ increases by $4.9-6.7 \mathrm{ppbv}$ before dawn (02:00-07:00 LT) and by 8.5-9.0 ppbv in the afternoon (13:00-18:00 LT). The much more significant increase in $\mathrm{O}_{3}$ in the afternoon in July 2015 is likely to be due to the stronger photochemical production, which is affected by both meteorological conditions and $\mathrm{O}_{3}$ precursor emissions. The slight increase in nighttime $\mathrm{O}_{3}$ reflects the residual effect of the daytime increase, despite strong nighttime titration by NO. This result is very different from the trends over the US, where summertime daytime $\mathrm{O}_{3}$ declined over the past decades is contrasted with the nighttime growth in all seasons (Yan et al., 2018a). Considering that the nighttime $\mathrm{O}_{3}$ is easily titrated by $\mathrm{NO}$ and the MDA8 $\mathrm{O}_{3}$ is a good indicator for the overall $\mathrm{O}_{3}$ pollution condition, we focus on the MDA8 $\mathrm{O}_{3}$ changes over CEC between July 2003 and July 2015 instead of daily mean $\mathrm{O}_{3}$.

\section{Impacts of meteorology on surface $\mathrm{O}_{3}$}

We performed sensitivity tests to investigate the effects of meteorology and emissions on the MDA8 $\mathrm{O}_{3}$ over CEC. The contributions of meteorological change to the change in MDA8 $\mathrm{O}_{3}$ are defined by the 03E15M-03E03M and $15 \mathrm{E} 15 \mathrm{M}-15 \mathrm{E} 03 \mathrm{M}$ simulations. Here we discuss only $03 \mathrm{E} 15 \mathrm{M}-03 \mathrm{E} 03 \mathrm{M}$ in detail, as the results of $15 \mathrm{E} 15 \mathrm{M}-15 \mathrm{E} 03 \mathrm{M}$ are similar. The spatial distributions of $\mathrm{O}_{3}$ precursors $\left(\mathrm{NO}_{2}\right.$ and NMVOCs) for the different simulation scenarios and their differences are shown in Figs. S10 and S11, which can better explain these results. A detailed description is given in the Supplement.

The regional averaged MDA $8 \mathrm{O}_{3}$ simulated by $03 \mathrm{E} 15 \mathrm{M}$ is $68.7 \pm 7.1 \mathrm{ppbv}$, comparable to that simulated by $15 \mathrm{E} 03 \mathrm{M}$ $(69.6 \pm 8.9 \mathrm{ppbv})$, indicating the comparable contributions made by the changes in meteorology and in emissions. Figure 5 shows the spatial distribution of MDA8 $\mathrm{O}_{3}$ changes among different simulation scenarios. The regional mean MDA8 $\mathrm{O}_{3}$ of CEC is approximately $5.8 \pm 3.9$ ppbv $(5 \%-$ $95 \%$ interval: $-0.1-12.4 \mathrm{ppbv}$ ) higher in scenario $03 \mathrm{E} 15 \mathrm{M}$ than in 03E03M (Fig. 5a) over the central part of CEC (106 to $115^{\circ} \mathrm{E}, 28$ to $40^{\circ} \mathrm{N}$ ). Over the eastern coastal areas (115 to $120^{\circ} \mathrm{E}, 28$ to $40^{\circ} \mathrm{N}$ ), however, the MDA8 $\mathrm{O}_{3}$ in the former scenario is less than in the latter by approximately $-0.8 \pm 3.5$ ppbv ( $5 \%-95 \%$ interval: $-6.8-3.8 \mathrm{ppbv})$, indicating great spatial variation in the influence of meteorological changes.

Atmospheric circulation patterns complicate the prediction of $\mathrm{O}_{3}$ concentrations in a specific region (He et al., 2012). The geopotential height map in Fig. S12 shows a highpressure system over CEC at $850 \mathrm{hPa}$ in July 2015. It is well known that high- $\mathrm{O}_{3}$-pollution events preferentially occur under high-pressure conditions (Wild et al., 2004; Zhao et al., 
Table 2. Monthly mean (standard deviation) $\mathrm{MDA} 8 \mathrm{O}_{3}$ over $\mathrm{CEC}$ based on four model simulations. $\triangle \mathrm{MDA} 8 \mathrm{O}_{3}$ represents the difference in MDA8 $\mathrm{O}_{3}$ concentrations between the 2015 standard simulation and 2003 standard simulation: $\triangle$ MDA8 $\mathrm{O}_{3}=\mathrm{MDA}_{8} \mathrm{O}_{3}(2015)-\mathrm{MDA} 8$ $\mathrm{O}_{3}$ (2003). MDA8 $\mathrm{O}_{3}>75 \mathrm{ppbv}$ indicates the region of $\mathrm{MDA} 8 \mathrm{O}_{3}$ exceeding the Level II National Ambient Air Quality Standard (75 ppbv) in July 2015.

\begin{tabular}{|c|c|c|c|c|c|}
\hline Region & Description & 03E03M & 03E15M & $15 \mathrm{E} 03 \mathrm{M}$ & $15 \mathrm{E} 15 \mathrm{M}$ \\
\hline \multirow[t]{4}{*}{ CEC } & regional mean & $65.5(7.9)$ & $68.7(7.1)$ & $69.6(8.9)$ & $74.4(8.7)$ \\
\hline & $\Delta \mathrm{MDA} 8 \mathrm{O}_{3} \geq 0$ & $65.6(8.2)$ & $69.4(6.9)$ & $69.8(9.1)$ & $75.6(8.2)$ \\
\hline & $\Delta$ MDA8 $\mathrm{O}_{3} \geq 5.0$ & $65.6(8.7)$ & $70.6(6.7)$ & $70.0(9.7)$ & $77.4(7.7)$ \\
\hline & $\Delta$ MDA $8 \mathrm{O}_{3} \geq 10$ & $64.3(9.7)$ & $71.0(7.4)$ & $68.8(10.8)$ & $78.0(8.4)$ \\
\hline Region with MDA8 & regional mean & $71.0(4.5)$ & $74.7(4.2)$ & $76.0(5.2)$ & $82.2(4.7)$ \\
\hline \multirow[t]{3}{*}{$\mathrm{O}_{3}>75 \mathrm{ppbv}$} & $\triangle$ MDA $8 \mathrm{O}_{3} \geq 0$ & $71.0(4.5)$ & $74.7(4.2)$ & $76.0(5.2)$ & $82.2(4.7)$ \\
\hline & $\triangle \mathrm{MDA} 8 \mathrm{O}_{3} \geq 5.0$ & $70.9(4.5)$ & $74.7(4.2)$ & $75.9(5.3)$ & $82.3(4.7)$ \\
\hline & $\Delta$ MDA8 $\mathrm{O}_{3} \geq 10$ & $70.5(4.8)$ & $75.5(4.5)$ & $75.7(5.6)$ & $83.4(4.8)$ \\
\hline
\end{tabular}

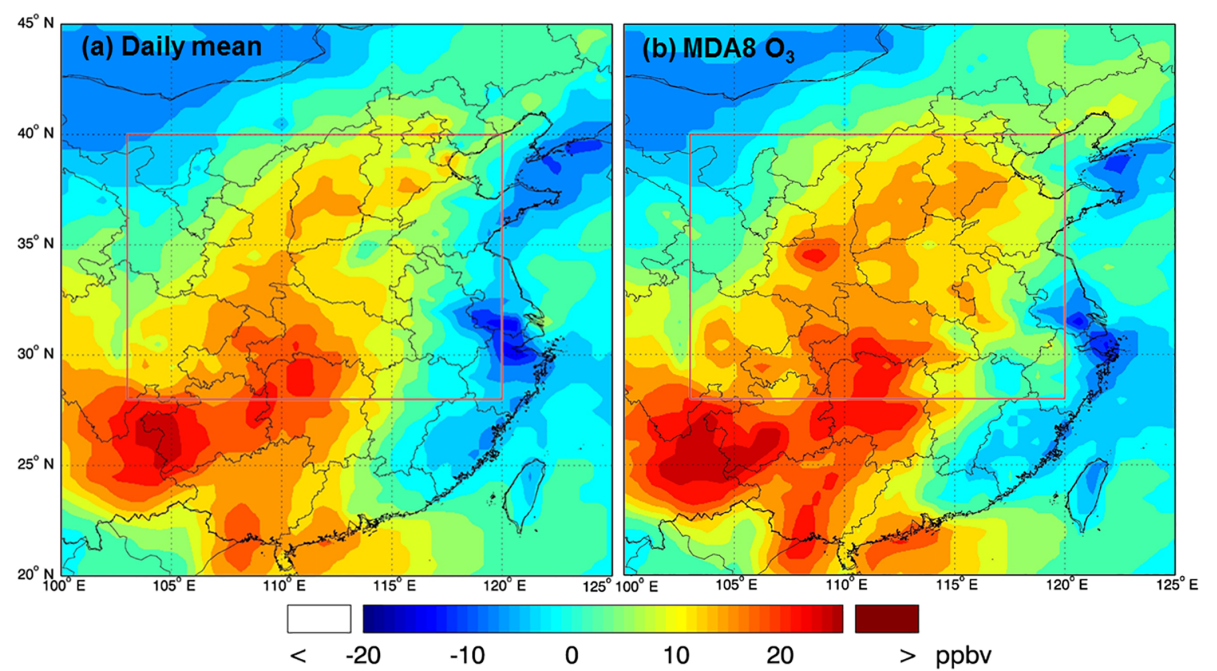

Figure 3. Differences in monthly mean surface $\mathrm{O}_{3}$ in July of 2003 and 2015 (2015-2003) for daily mean $\mathrm{O}_{3}$ (a) and $\mathrm{MDA}$ ( $\mathrm{O}_{3}$ (b) simulated by 2003 and 2015 standard simulations.

2009; Xu et al., 2011). This is because the relatively high geopotential height induces a stable weather condition. Neither horizontal nor vertical transport is strong, which favors the accumulation of atmospheric pollutants such as surface $\mathrm{O}_{3}$. We found that in July 2015 the wind speeds over the southern and eastern boundaries of CEC were much lower than those in July 2003 (Fig. S13), leading to much lower $\mathrm{O}_{3}$ flux across these two boundaries. The low $\mathrm{O}_{3}$ over southern CEC in July 2003 was mainly due to the strong southwesterly wind, decreasing $\mathrm{O}_{3}$ levels in this area. However, a large amount of $\mathrm{O}_{3}$ and its precursors from the central part of CEC was transported to the eastern coastal area, which increased $\mathrm{O}_{3}$ concentrations there (refer to Table 4: about $1343 \mathrm{Gg}_{\text {month }}{ }^{-1}$ of $\mathrm{O}_{3}$ transported out across the east boundary). Conversely, in July 2015, only a small amount of $\mathrm{O}_{3}$ (refer to Table 4: $-61 \mathrm{Gg} \mathrm{month}^{-1}$ ) and its precursors was transported away from the ocean by the weak southeasterly winds, which only decreased the $\mathrm{O}_{3}$ levels in the coastal area.
However, in the central part of CEC, the wind was weak, leading to accumulating $\mathrm{O}_{3}$ pollution in this area. As a result, the $\mathrm{O}_{3}$ concentrations increased in the central part of CEC and decreased in the eastern coastal area in July 2015 compared to July 2003. More detailed and quantitative results on $\mathrm{O}_{3}$ transport flux will be discussed in Sect. 6 .

In addition to the wind, air temperature and relative humidity are two other important meteorological parameters that can affect atmospheric $\mathrm{O}_{3}$ concentrations. High temperatures tend to accelerate the rate of ozone-related photochemical reactions, promoting $\mathrm{O}_{3}$ production (Ramsey et al., 2014). Cloud indirectly affects $\mathrm{O}_{3}$ pollution by blocking solar radiation, thus affecting the emission of BVOCs and the photochemical production of $\mathrm{O}_{3}$ (Lin et al., 2009). Figure $\mathrm{S} 14$ shows the simulated monthly mean spatial distributions of air temperature and relative humidity in July 2003 and July 2015. The simulated air temperatures in 2003 and 2015 were $300.6 \pm 3.2$ and $300.5 \pm 3.2 \mathrm{~K}$, respectively, almost 


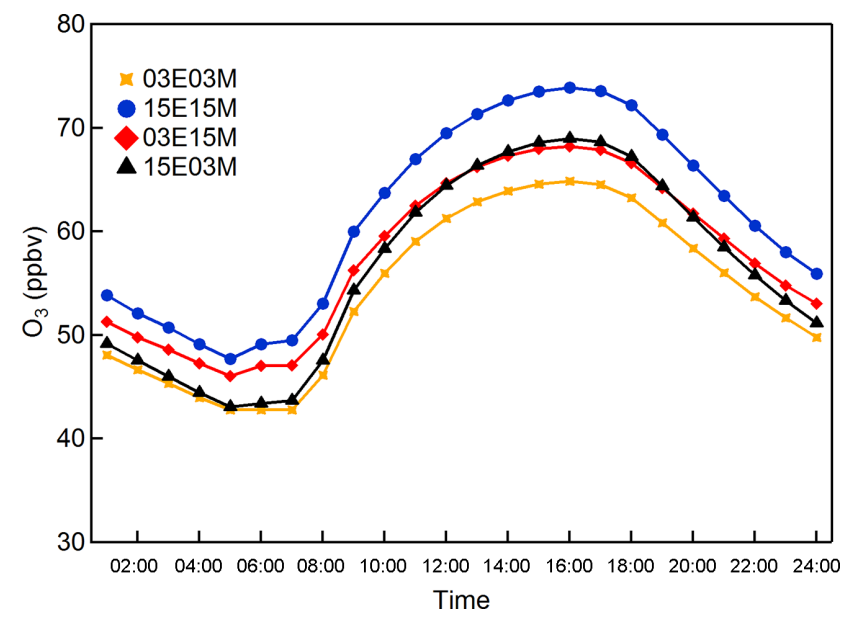

Figure 4. Averaged diurnal variations in surface $\mathrm{O}_{3}$ over CEC derived from four simulation results.

at the same level. The simulated relative humidity in 2003 was $82 \pm 10 \%$, a little higher than in $2015(77 \pm 12 \%)$. The average net $\mathrm{O}_{3}$ production over CEC simulated by 03E03M $\left(11.7 \mathrm{ppbv}^{-1 a y^{-1}}\right)$ is very close to that simulated by $03 \mathrm{E} 15 \mathrm{M}$ $\left(11.9 \mathrm{ppbv} \mathrm{day}^{-1}\right.$ ) (Table 4), suggesting that meteorological factors in 2003 and 2015 did not greatly change $\mathrm{O}_{3}$ photochemical reactions. Therefore, neither air temperature nor relative humidity plays an important role in explaining the difference in surface $\mathrm{O}_{3}$ between 2003 and 2015.

We summarize the regional mean $\mathrm{O}_{3}$ over $\mathrm{CEC}$ and the regions with MDA8 $\mathrm{O}_{3}>75 \mathrm{ppbv}$ in Table 2. To avoid the influence of uneven spatial distributions of $\mathrm{O}_{3}$ concentration changes, we performed a gradient analysis, which selected different levels for the difference of MDA8 $\mathrm{O}_{3}(\triangle \mathrm{MDA} 8$ $\mathrm{O}_{3}$ ) between 2003 standard and 2015 standard simulation $(15 \mathrm{E} 15 \mathrm{M}-03 \mathrm{E} 03 \mathrm{M})$. The differences in MDA8 $\mathrm{O}_{3}$ were analyzed in four ways: regional mean, $\triangle \mathrm{MDA} 8 \mathrm{O}_{3} \geq 0 \mathrm{ppbv}$, $\triangle \mathrm{MDA} 8 \mathrm{O}_{3} \geq 5 \mathrm{ppbv}$ and $\triangle \mathrm{MDA} 8 \mathrm{O}_{3} \geq 10 \mathrm{ppbv}$. For the regional mean over $\mathrm{CEC}$, the increase in MDA8 $\mathrm{O}_{3}$ driven by meteorology is approximately $3.1 \pm 4.9 \mathrm{ppbv}$, from $65.5 \pm$ $7.9 \mathrm{ppbv}(03 \mathrm{E} 03 \mathrm{M})$ to $68.7 \pm 7.1 \mathrm{ppbv}(03 \mathrm{E} 15 \mathrm{M})$. Where $\triangle$ MDA $8 \mathrm{O}_{3} \geq 10$ ppbv, mostly over the central part of CEC, the MDA8 $\mathrm{O}_{3}$ increases by $6.7 \pm 3.4 \mathrm{ppbv}$ from $64.3 \pm$ $9.7 \mathrm{ppbv}$ to $71.0 \pm 7.4 \mathrm{ppbv}$ due to the meteorological change. Thus, the meteorological conditions have a greater impact on the $\mathrm{O}_{3}$ change when the difference between 2003 and 2015 is higher than $10 \mathrm{ppbv}$. Similar results are also found in regions with MDA8 $\mathrm{O}_{3}>75 \mathrm{ppbv}$, where the increase in the $\mathrm{O}_{3}$ concentration is approximately $3.6 \pm 3.2$ and $5.1 \pm 2.5 \mathrm{ppbv}$ for the regional mean and for the $\triangle \mathrm{MDA} 8 \mathrm{O}_{3} \geq 10$ case, respectively. This indicates that surface $\mathrm{O}_{3}$ levels are more sensitive to meteorological conditions in regions with larger $\mathrm{O}_{3}$ increase.

\section{Impact of emission changes on surface $\mathrm{O}_{3}$}

As described above, the impact of emission changes on MDA8 $\mathrm{O}_{3}$ between 2003 and 2015 can be estimated by $15 \mathrm{E} 03 \mathrm{M}-03 \mathrm{E} 03 \mathrm{M}$ or $15 \mathrm{E} 15 \mathrm{M}-03 \mathrm{E} 15 \mathrm{M}$. Here we discuss $15 \mathrm{E} 03 \mathrm{M}-03 \mathrm{E} 03 \mathrm{M}$ in detail. Similar results were found from $15 \mathrm{E} 15 \mathrm{M}-03 \mathrm{E} 15 \mathrm{M}$.

Figure $5 \mathrm{~b}$ shows the contributions of emission changes to surface $\mathrm{O}_{3}$ levels. The emission change leads to an increase in MDA8 $\mathrm{O}_{3}$ over most areas of CEC, and it has a much smaller spatial variability than the meteorological change does (Fig. 5a). Compared to the influence of the meteorological change (03E15M - 03E03M: $3.1 \pm 4.9 \mathrm{ppbv})$, the increase in emissions leads to a higher regional mean $\mathrm{O}_{3}$ increase (15E03M - 03E03M: $4.0 \pm 1.9 \mathrm{ppbv})$ over CEC (Table 2). The changes in $\mathrm{NO}_{2}$ and NMVOCs also indicate the impact of emission changes is larger than that of meteorological change (Figs. S10 and S11). In contrast, for the case of $\triangle \mathrm{MDA} 8 \mathrm{O}_{3} \geq 10 \mathrm{ppbv}$, the influence of emission change on $\mathrm{O}_{3}(15 \mathrm{E} 03 \mathrm{M}-03 \mathrm{E} 03 \mathrm{M}$ : $4.5 \pm 2.1 \mathrm{ppbv})$ is smaller than that of the meteorological field change $(03 \mathrm{E} 15 \mathrm{M}-03 \mathrm{E} 03 \mathrm{M}$ : $6.7 \pm 3.4 \mathrm{ppbv})$. The increases in MDA8 $\mathrm{O}_{3}$ due to emission change are about $3.5 \pm 1.4 \mathrm{ppbv}(5 \%-95 \%$ interval: 1.6-6.0 ppbv) and $5.6 \pm 1.8 \mathrm{ppbv}(5 \%-95 \%$ interval: $2.2-$ $8.4 \mathrm{ppbv}$ ) over the central and eastern parts of CEC, which are different from the spatial pattern caused by meteorological change. It is worth noting that in the polluted regions where MDA8 $\mathrm{O}_{3}>75 \mathrm{ppbv}$, the contribution of emission change increases from $5.0 \pm 1.8 \mathrm{ppbv}$ for the $\triangle \mathrm{MDA} 8 \mathrm{O}_{3} \geq$ $0 \mathrm{ppbv}$ case to $5.2 \pm 1.7 \mathrm{ppbv}$ for the $\triangle \mathrm{MDA} 8 \mathrm{O}_{3} \geq 10 \mathrm{ppbv}$ case, whilst the contribution of meteorology change increases from $3.7 \pm 3.2$ to $5.0 \pm 2.5 \mathrm{ppbv}$. Even if the $\triangle \mathrm{MDA} 8$ $\mathrm{O}_{3}$ is greater than $10 \mathrm{ppbv}$, the $\mathrm{O}_{3}$ increase caused by emission change is still a little higher than that caused by meteorological change, indicating the dominant effect of emissions on $\mathrm{O}_{3}$ pollution in the highly polluted regions.

We summarize the emissions of $\mathrm{NO}_{x}, \mathrm{CO}$ and NMVOCs over CEC for July 2003 and July 2015 in Table 3. The anthropogenic $\mathrm{NO}_{x}$ emissions increased from $397 \mathrm{Gg}$ month ${ }^{-1}$ in July 2003 to $683 \mathrm{Gg} \mathrm{month}^{-1}$ in July 2015. The anthropogenic NMVOCs also increased significantly, with the NMVOC emissions increasing from $190 \mathrm{Gg} \mathrm{C}$ month $^{-1}$ in July 2003 to $365 \mathrm{Gg} \mathrm{C}$ month $^{-1}$ in July 2015 . The spatial distributions of anthropogenic $\mathrm{NO}_{x}$ and NMVOC emissions in Figs. S15 and S16 also indicate significant increases from 2003 to 2015. Anthropogenic CO emissions increased from $4619 \mathrm{Gg} \mathrm{month}^{-1}$ in July 2003 to $6011 \mathrm{Gg}$ month $^{-1}$ in July 2015 . The natural BVOCs, which are greatly affected by meteorological conditions, remained unchanged between 2003 and 2015. Biomass burning often occurs sequentially from south to north in CEC in the spring harvest season and lasts from late May to late June (Chen et al., 2017). In July, the biomass burning emissions generally decrease to approximately $1 \%$ of the anthropogenic emissions (not shown). 

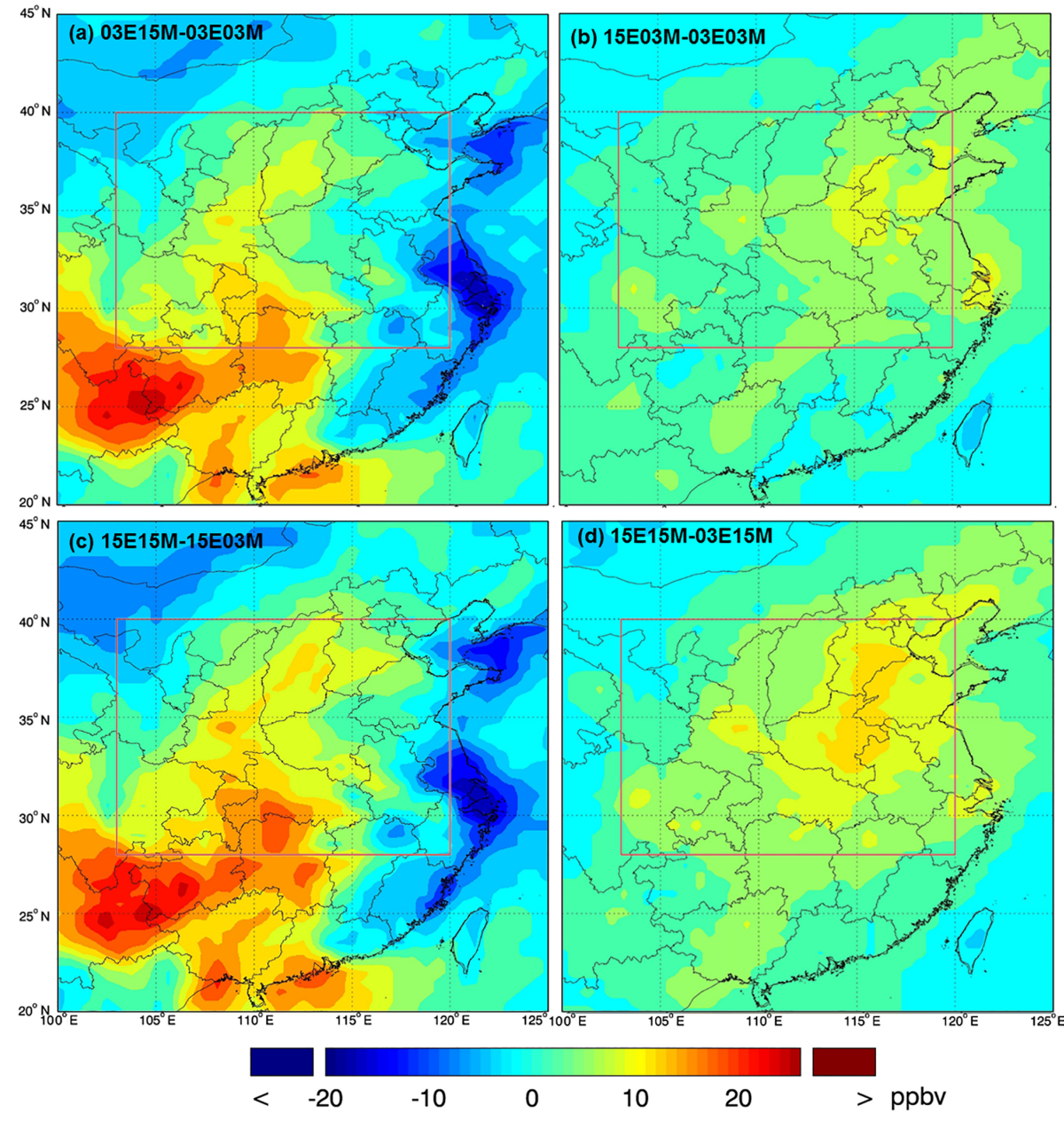

Figure 5. (a) Contributions of meteorological changes to surface MDA8 $\mathrm{O}_{3}$, comparing 03E15M and 03E03M (2003 standard) simulations. (b) Contributions of emission changes to surface $\mathrm{MDA} 8 \mathrm{O}_{3}$, comparing 15E03M and 03E03M (2003 standard) simulations. (c) Contributions of meteorological changes to surface MDA8 $\mathrm{O}_{3}$, comparing 15E15M (2015 standard) and 15E03M simulations. (d) Contributions of emission changes to surface MDA8 $\mathrm{O}_{3}$, comparing 15E15M (2015 standard) and 03E15M simulations.

Therefore, the effect of the emission change on $\mathrm{O}_{3}$ is primarily due to anthropogenic emissions of $\mathrm{NO}_{x}$ and NMVOCs.

To separate the effect of anthropogenic emissions from the effect of natural emission on $\mathrm{O}_{3}$ variability, we conducted two further simulations, $03 \mathrm{~N} 15 \mathrm{M}$ and $03 \mathrm{~V} 15 \mathrm{M}$ (see Sect. 2.2). Figure 6 shows the spatial distribution of the MDA8 $\mathrm{O}_{3}$ differences between the 2015 standard simulation and these two simulations. Anthropogenic NMVOCs (Fig. 6a) have a great impact on MDA8 $\mathrm{O}_{3}$ over the eastern part of CEC, increasing MDA8 $\mathrm{O}_{3}$ by approximately $2.5 \pm 0.8$ ppbv ( $5 \%-95 \%$ interval: $1.1-3.7 \mathrm{ppbv}$ ). The emissions of NMVOCs increased greatly over the eastern part of CEC (see Fig. S16). The change in MDA8 $\mathrm{O}_{3}$ due to anthropogenic NMVOCs varies from -0.5 to $5.1 \mathrm{ppbv}$ over different subregions of CEC, with a regional mean of $1.4 \pm$ $1.1 \mathrm{ppbv}$. The effect of anthropogenic $\mathrm{NO}_{x}$ (Fig. 6b), in comparison, is more complicated. From 2003 to 2015, MDA8 O 3 declined in some cities such as Tianjin, Ji'nan, Taiyuan and
Nanjing in the eastern part of CEC, but increased in the central and western parts (regional mean: $2.8 \pm 0.9 \mathrm{ppbv}, 5 \%$ 95\% interval: $1.4-4.1 \mathrm{ppbv})$. The change in MDA8 $\mathrm{O}_{3}$ due to anthropogenic $\mathrm{NO}_{x}$ varies from -3.1 to $6.7 \mathrm{ppbv}$, with a regional mean of $2.5 \pm 1.1$ ppbv over CEC ( $5 \%-95 \%$ interval: $-0.2-3.3 \mathrm{ppbv})$. The reduction of $\mathrm{O}_{3}$ in the urban area is likely to be due to the abundant $\mathrm{NO}_{x}$ from industrial and traffic sources. Beijing shows a slight decrease in $\mathrm{NO}_{x}$ emissions, leading to a slight change in $\mathrm{O}_{3}$ levels. In most rural areas of CEC, $\mathrm{O}_{3}$ formation tends to be limited by the concentrations of $\mathrm{NO}_{x}$ (the so-called $\mathrm{NO}_{x}$-limited regime). Thus, $\mathrm{O}_{3}$ is increased significantly as we increase the anthropogenic emissions of $\mathrm{NO}_{x}$. A VOC-limited regime in a few urban areas and a $\mathrm{NO}_{x}$-limited or transition regime in regional rural areas of CEC have been reported in some observational and model simulation studies (Wang et al., 2017, and references therein). The change in BVOC emissions only leads to a small change in $\mathrm{MDA} 8 \mathrm{O}_{3}$ over $\mathrm{CEC}$, 
Table 3. Emissions of $\mathrm{NO}_{x}, \mathrm{CO}$ and NMVOCs over CEC for July 2003 and July 2015, including anthropogenic emissions and biogenic emissions. Units: $\mathrm{NO}, \mathrm{CO}$ and $\mathrm{CH}_{2} \mathrm{O}$ : $\mathrm{Gg}_{\text {month }}{ }^{-1}$; others: $\mathrm{Gg} \mathrm{C}_{\text {month }}{ }^{-1}$.

\begin{tabular}{|c|c|c|c|c|c|}
\hline Species & 2003 & 2015 & Species & 2003 & 2015 \\
\hline \multicolumn{6}{|c|}{ Anthropogenic emissions } \\
\hline NO & 397 & 683 & Acetaldehyde & 2.7 & 3.0 \\
\hline $\mathrm{CO}$ & 4619 & 6011 & $\mathrm{PRPE}^{\mathrm{b}}$ & 39 & 70 \\
\hline $\mathrm{ALK} 4^{\mathrm{a}}$ & 81 & 184 & $\mathrm{C}_{3} \mathrm{H}_{8}$ & 35 & 56 \\
\hline Acetone & 4.2 & 9.9 & $\mathrm{CH}_{2} \mathrm{O}$ & 6.4 & 7.4 \\
\hline Methyl ethyl ketone & 1.2 & 3.6 & $\mathrm{C}_{2} \mathrm{H}_{6}$ & 21 & 32 \\
\hline \multicolumn{6}{|l|}{ Biogenic emissions } \\
\hline Isoprene & 276 & 275 & $\beta$-Pinene & 18.4 & 17.4 \\
\hline Acetone & 23.0 & 22.0 & 3-Carene & 15.3 & 14.3 \\
\hline PRPE & 21.0 & 21.0 & Ocimene & 7.3 & 7.1 \\
\hline$\alpha$-Pinene & 25.9 & 23.8 & Acetaldehyde & 10.0 & 9.0 \\
\hline Total monoterpenes & 90 & 85 & Other monoterpenes & 11.0 & 11.0 \\
\hline
\end{tabular}

a ALK4: alkanes and other nonaromatic compounds that react only with $\mathrm{OH}$ and have $k_{\mathrm{OH}}$ between $5 \times 10^{3}$ and $1 \times 10^{4} \mathrm{ppm}^{-1} \mathrm{~min}^{-1}$. b PRPE: OLE1+OLE2, OLE1: alkenes (other than ethene) with $k_{\mathrm{OH}}<7 \times 10^{4} \mathrm{ppm}^{-1} \mathrm{~min}^{-1}$; OLE2: alkenes with $k_{\mathrm{OH}}>7 \times 10^{4} \mathrm{ppm}^{-1} \mathrm{~min}^{-1}$.

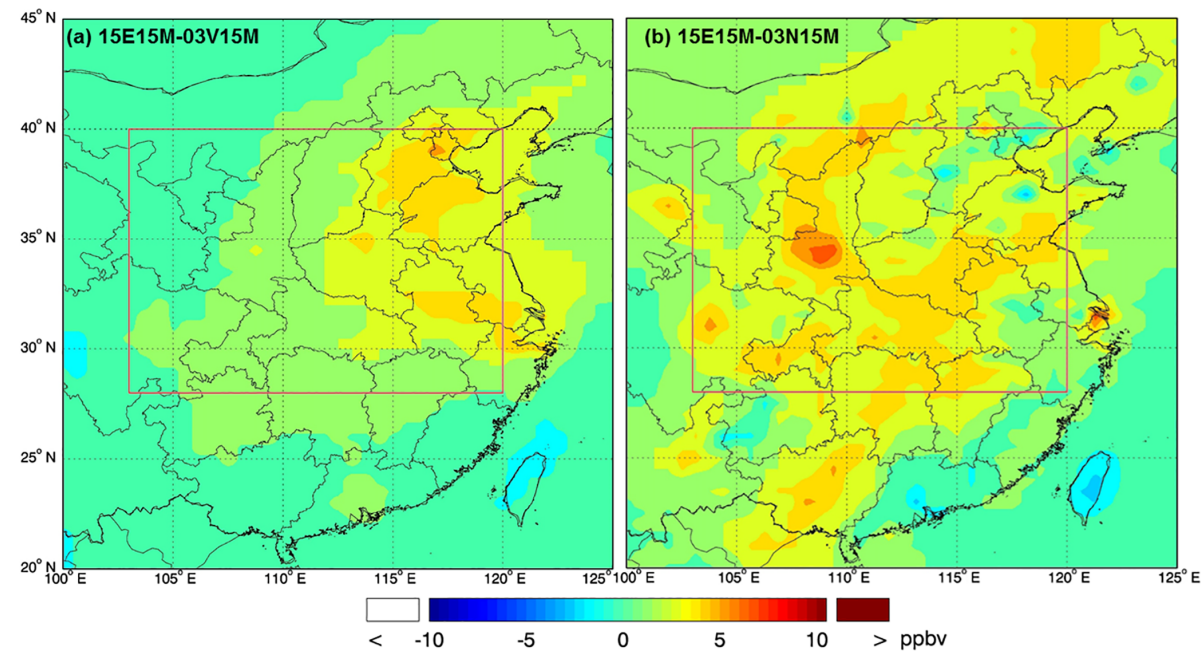

Figure 6. Effects of anthropogenic NMVOCs (a) and $\mathrm{NO}_{x}$ (b) emission changes on surface $\mathrm{MDA}_{8} \mathrm{O}_{3}$ concentrations between 2003 and 2015 when other emissions and meteorological parameters are fixed at 2015 levels.

resulting in an increase in the $\mathrm{O}_{3}$ level of only $0.3 \mathrm{ppbv}$ (not shown), mostly due to the change in meteorological conditions. Therefore, if the meteorological conditions are fixed as the 2015 conditions, the increase in anthropogenic NMVOCs is the most important factor responsible for the $\mathrm{O}_{3}$ increase over the eastern part of CEC, whereas $\mathrm{NO}_{x}$ emissions tend to increase MDA8 $\mathrm{O}_{3}$ over central and western parts but decrease it in a few urban areas over eastern parts of CEC.

\section{Budget analyses}

Ozone concentrations are determined by chemical and dynamic processes including transport, chemical production and loss, and deposition. In this section, we discuss the effects of these processes on the surface $\mathrm{O}_{3}$ over CEC.

Table 4 documents the horizontal and vertical mass fluxes of $\mathrm{O}_{3}$ over CEC at four boundaries (north, east, south and west). The flux at each boundary was calculated from the surface to $850 \mathrm{hPa}$. In July 2003, the air flows into CEC through the south boundary, and then out across the other three boundaries. In contrast, the air masses flow into this area across the east boundary in July 2015, and then out across the left three boundaries. The larger $\mathrm{O}_{3}$ flux from each boundary in July 2003 is due to stronger winds. Compared to the 03E03M simulation $\left(-897 \mathrm{Gg}\right.$ month $^{-1}$; negative value means export of $\mathrm{O}_{3}$ from this region), 03E15M shows a much 
Table 4. Horizontal and vertical flux $\left(\mathrm{Gg}_{\mathrm{month}}{ }^{-1}\right)$, photochemical production and loss $\left(\mathrm{Gg} \mathrm{month}^{-1}\right.$; the numbers in the parentheses are in ppbv day $\left.{ }^{-1}\right)$, and dry deposition $\left(\mathrm{Gg}\right.$ month $^{-1}$ ) of $\mathrm{O}_{3}$ over CEC from the surface to $850 \mathrm{hPa}$ based on four types of simulations. For horizontal flux, positive values indicate eastward or northward transport. For vertical fluxes, positive values indicate upward transport. "Total" refers to the sum of horizontal and vertical transport. Net photochemical $\mathrm{O}_{3}$ production is the difference between production and loss of $\mathrm{O}_{3}$.

\begin{tabular}{lllrrrr}
\hline Processes & & Boundary & 03E03M & $03 \mathrm{E} 15 \mathrm{M}$ & $15 \mathrm{E} 03 \mathrm{M}$ & $15 \mathrm{E} 15 \mathrm{M}$ \\
\hline \multirow{2}{*}{ Transport } & Horizontal & $103^{\circ} \mathrm{E}$ & -176 & -145 & -190 & -149 \\
& & $120^{\circ} \mathrm{E}$ & 1343 & -129 & 1450 & -61 \\
& & $28^{\circ} \mathrm{N}$ & 1914 & -100 & 1906 & -178 \\
& & $40^{\circ} \mathrm{N}$ & 440 & 327 & 488 & 351 \\
\cline { 2 - 7 } & Vertical & $850 \mathrm{hPa}$ & 852 & -43 & 877 & -116 \\
\hline \multirow{2}{*}{ Photochemical } & Total & & -897 & -401 & -1100 & -502 \\
& Production & & $2850(20.5)$ & $2890(20.7)$ & $3511(25.2)$ & $3532(25.4)$ \\
& Loss & & $1221(8.8)$ & $1232(8.9)$ & $1344(9.7)$ & $1373(9.9)$ \\
& Net & & $1629(11.7)$ & $1657(11.9)$ & $2166(15.6)$ & $2158(15.5)$ \\
\hline Dry deposition & & & 156 & 166 & 162 & 180 \\
\hline
\end{tabular}

lower $\mathrm{O}_{3}$ flux $\left(-401 \mathrm{Gg}\right.$ month $\left.^{-1}\right)$, indicating that weather conditions in 2015 play a more important role in pollutant accumulation, which is consistent with our analysis in Sect. 4. The larger $\mathrm{O}_{3}$ flux in $15 \mathrm{E} 03 \mathrm{M}\left(-1100 \mathrm{Gg}_{\text {month }}{ }^{-1}\right)$ in comparison to the $03 \mathrm{E} 03 \mathrm{M}$ simulation, however, is mostly due to the increased precursor emissions in 2015.

Table 4 also shows the chemical production and loss of $\mathrm{O}_{3}$ over CEC from the surface to $850 \mathrm{hPa}$. The net photochemical production of $\mathrm{O}_{3}$ in July $2015\left(2158 \mathrm{Gg}\right.$ month $^{-1}$ or $15.5 \mathrm{ppbv}^{-1} \mathrm{day}^{-1}$ ) is higher than that in July 2003

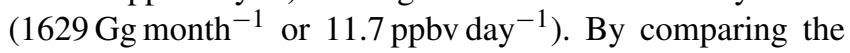
03E03M simulation with the 03E15M simulation, we find that the weather conditions in 2015 do not promote excessive net $\mathrm{O}_{3}$ production $\left(03 \mathrm{E} 15 \mathrm{M}: 1657 \mathrm{Gg} \mathrm{month}^{-1}\right.$ or $11.9 \mathrm{ppbv}$ day $^{-1}$ ), almost the same level as 03E03M simulation. In comparison, due to more $\mathrm{O}_{3}$ precursor emissions in 2015 , the net $\mathrm{O}_{3}$ production by $15 \mathrm{E} 03 \mathrm{M}\left(2166 \mathrm{Gg}_{\text {month }}{ }^{-1}\right.$ or $15.6 \mathrm{ppbv}_{\mathrm{day}}{ }^{-1}$ ) is much higher than the $03 \mathrm{E} 03 \mathrm{M}$ simulation. The net photochemical $\mathrm{O}_{3}$ production in this study is similar to the result of $\mathrm{Li}$ et al. (2007), who reported a net production of $10-32 \mathrm{ppbv}^{-1} \mathrm{y}^{-1}$ at three mountain sites over CEC in 2004. Deposition (mainly dry deposition) is another factor that affects $\mathrm{O}_{3}$ concentrations. The 03E15M simulation shows an increase in $\mathrm{O}_{3}$ dry deposition by only $10 \mathrm{Gg} \mathrm{month}{ }^{-1}$, compared to the $03 \mathrm{E} 03 \mathrm{M}$ simulation $\left(156 \mathrm{Gg} \mathrm{month}^{-1}\right)$. Thus dry deposition is less affected by changes in weather conditions.

As shown in Table 4, the $\mathrm{O}_{3}$ budget analysis indicates CEC is a strong photochemical source region in both 2003 and 2015. The photochemically produced $\mathrm{O}_{3}$ is mostly exported by transport and to a lesser extent removed by dry deposition. In July 2003, about half of the net photochemically formed $\mathrm{O}_{3}$ in the CEC region was removed by transport ( 897 out of $1629 \mathrm{Gg} \mathrm{month}^{-1}$ ). In comparison, only onefourth of the net photochemically produced $\mathrm{O}_{3}$ (502 out of $2158 \mathrm{Gg} \mathrm{month}^{-1}$ ) was transported out of CEC in July 2015. Comparing the results of the 2003 and 2015 standard simulations $(15 \mathrm{E} 15 \mathrm{M}-03 \mathrm{E} 03 \mathrm{M})$, we find less $\mathrm{O}_{3}$ export from CEC in 2015 than in 2003, which means about $395 \mathrm{Gg} \mathrm{month}^{-1}$ (2015-2003) of $\mathrm{O}_{3}$ was accumulated in this region. In addition, net $\mathrm{O}_{3}$ production increased by $529 \mathrm{Gg} \mathrm{month}^{-1}$ and $\mathrm{O}_{3}$ dry deposition only increased by $24 \mathrm{Gg}$ month $^{-1}$ from the 2003 standard simulation to 2015 standard simulation. As a result, the increase in $\mathrm{O}_{3}$ concentrations from July 2003 to July 2015 should be due to the enhanced photochemical production (mainly due to the increased emissions) and the weakened export (due to the meteorological conditions).

\section{Conclusions}

In this study, we used the global GEOS-Chem model and its Asian nested model to simulate surface $\mathrm{O}_{3}$ over central eastern China between July 2003 and July 2015. We found that the regional averaged concentration of MDA8 $\mathrm{O}_{3}$ increased from $65.5 \pm 7.9 \mathrm{ppbv}$ in 2003 to $74.4 \pm 8.7 \mathrm{ppbv}$ in 2015. The increase in the regional average MDA8 $\mathrm{O}_{3}$ due to emission changes $(4.0 \pm 1.9 \mathrm{ppbv})$ is higher than that caused by meteorological changes $(3.1 \pm 4.9 \mathrm{ppbv})$ compared with the 2003 standard simulation. The effects of meteorological changes have a larger spatial variability than those of emission changes. The increase in anthropogenic NMVOC emissions increased $\mathrm{O}_{3}$ over the eastern part of CEC, whereas the increased anthropogenic $\mathrm{NO}_{x}$ emissions dominated the increase in $\mathrm{O}_{3}$ over the central and western parts of CEC but decreased $\mathrm{O}_{3}$ levels in a few urban areas over eastern CEC. The $\mathrm{O}_{3}$ formation over most areas is in a $\mathrm{NO}_{x}$-limited or transition regime, whereas a few urban areas tend to be in a VOC-limited regime. The increase in surface $\mathrm{O}_{3}$ is mainly 
via photochemical production and transport processes. The meteorological conditions (mostly due to wind patterns) in July 2015 tended to accumulate pollution and reduced $\mathrm{O}_{3}$ export over the central part of CEC and thus enhanced $\mathrm{O}_{3}$ levels there. Air temperature and relative humidity do not promote the $\mathrm{O}_{3}$ production in July 2015. The increased net $\mathrm{O}_{3}$ photochemical production is mostly due to increased precursor emissions.

Our results have implications for the formulation of effective control strategies for $\mathrm{O}_{3}$ air pollution in CEC. Although the simulated average effect of emission changes is larger than the effect of meteorological changes, the regions with larger $\mathrm{O}_{3}$ increases (e.g., $\triangle \mathrm{MDA} 8 \mathrm{O}_{3} \geq 10 \mathrm{ppbv}$ ) show a higher sensitivity to meteorology than to emission changes. The results imply that assessment of the effectiveness of regional and urban $\mathrm{O}_{3}$ control strategies needs to be placed in the context of meteorology. The $\mathrm{O}_{3}$ transport flux analysis further suggests that large-scale regional transport is an important contributor to the surface $\mathrm{O}_{3}$ increases from 2003 to 2015. Transport issues in local $\mathrm{O}_{3}$ control strategies should go beyond transport from neighboring areas (e.g., cities) and account for the long-distance transport (e.g., across provinces).

Data availability. The underlying research data can be accessed upon contact with the corresponding author (Likun Xue; xuelikun@sdu.edu.cn).

Supplement. The supplement related to this article is available online at: https://doi.org/10.5194/acp-19-1455-2019-supplement.

Author contributions. LS processed the data, conducted the GEOSChem simulation and wrote the paper. LX designed the research, supervised the data analysis and revised the paper. YW supervised the data analysis. LL, JL, RN, YY, LC and JL assisted with the model simulation and helped in the data analysis and paper correction. QZ and WW helped in paper correction.

Competing interests. The authors declare that they have no conflict of interest.

Special issue statement. This article is part of the special issue "Regional transport and transformation of air pollution in eastern China". It is not associated with a conference.

Acknowledgements. This research was supported by the National Key Research and Development Program of China (2016YFC0200500), the National Natural Science Foundation of China (41675118, 91544213, 41775115), the Qilu Youth Talent Program of Shandong University, the Jiangsu Collaborative
Innovation Center for Climate Change and the Taishan Scholars (ts201712003). The model simulations were performed at the Supercomputing Center of Shandong University in Weihai. We thank the Chinese National Environmental Monitoring Center for providing the observation data. Lei Sun acknowledges the support of the China Scholarship Council. We also appreciate the three anonymous reviewers for their helpful comments to improve the original submission.

Edited by: David Parrish

Reviewed by: three anonymous referees

\section{References}

Auvray, M. and Bey, I.: Long-range transport to Europe: Seasonal variations and implications for the European ozone budget, J. Geophys. Res.-Atmos, 110, D11303, https://doi.org/10.1029/2004JD005503, 2005.

Chen, J., Li, C., Ristovski, Z., Milic, A., Gu, Y., Islam, M. S., Wang, S., Hao, J., Zhang, H., He, C., Guo, H., Fu, H., Miljevic, B., Morawska, L., Thai, P., Fat, L., Pereira, G., Ding, A., Huang, X., and Dumka, U.: A review of biomass burning: Emissions and impacts on air quality, health and climate in China, Sci. Total Environ., 579, 1000-1034, https://doi.org/10.1016/j.scitotenv.2016.11.025, 2017.

China State Council: Twelfth Five-Year Plan on National Economy and Social Development of the People's Republic of China, available at: http://www.gov.cn/2011lh/content_1825838.htm, 2011 (in Chinese).

Cooper, O. R., Gao, R. S., Tarasick, D., Leblanc, T., and Sweeney, C.: Long-term ozone trends at rural ozone monitoring sites across the United States, 1990-2010, J. Geophys. Res.-Atmos., 117, D22307, https://doi.org/10.1029/2012JD018261, 2012.

Cooper, O. R., Parrish, D., Ziemke, J., Balashov, N., Cupeiro, M., Galbally, I., Gilge, S., Horowitz, L., Jensen, N., Lamarque, J.-F., Naik, V., Oltmans, S., Schwab, J., Shindell, D., Thompson, A., Thouret, V., Wang, Y., and Zbinden, R.: Global distribution and trends of tropospheric ozone: An observation-based review, Elem. Sci. Anth., 2, 000029, https://doi.org/10.12952/journal.elementa.000029, 2014.

Crutzen, P.: A discussion of the chemistry of some minor constituents in the stratosphere and troposphere, Pure Appl. Geophys., 106, 1385-1399, https://doi.org/10.1007/BF00881092, 1973.

Danielsen, E. F.: Stratospheric-tropospheric exchange based on radioactivity, ozone and potential vorticity, J. Atmos. Sci., 25, 502-518, https://doi.org/10.1175/15200469(1968)025<0502:STEBOR>2.0.CO;2, 1968.

Ding, A. J., Wang, T., Thouret, V., Cammas, J.-P., and Nédélec, P.: Tropospheric ozone climatology over Beijing: analysis of aircraft data from the MOZAIC program, Atmos. Chem. Phys., 8, 1-13, https://doi.org/10.5194/acp-8-1-2008, 2008.

Fan, Y., Fan, S. Zhang, H, Zu, F., Meng, Q., and He, J.: Characteristics of $\mathrm{SO}_{2}, \mathrm{NO}_{2}, \mathrm{O}_{3}$ volume fractions and their relationship with weather conditions at Linan in summer and winter, Trans. Atmos. Sci., 36 121-128, https://doi.org/10.13878/j.cnki.dqkxxb.2013.01.013, 2013 (in Chinese). 
Fu, Y. and Liao, H.: Simulation of the interannual variations of biogenic emissions of volatile organic compounds in China: Impacts on tropospheric ozone and secondary organic aerosol, Atmos. Environ., 59, 170-185, https://doi.org/10.1016/j.atmosenv.2012.05.053, 2012.

Gaudel, A., Cooper, O. R., Ancellet, G., Barret, B., Boynard, A., Burrows, J. P., Clerbaux, C., Coheur, P. F., Cuesta, J., Cuevas Agulló, E., and Doniki, S.: Tropospheric Ozone Assessment Report: Present-day distribution and trends of tropospheric ozone relevant to climate and global atmospheric chemistry model evaluation, Elem. Sci. Anth., 6, 39, https://doi.org/10.1525/elementa.291, 2018.

Guenther, A. B., Jiang, X., Heald, C. L., Sakulyanontvittaya, T., Duhl, T., Emmons, L. K., and Wang, X.: The Model of Emissions of Gases and Aerosols from Nature version 2.1 (MEGAN2.1): an extended and updated framework for modeling biogenic emissions, Geosci. Model Dev., 5, 1471-1492, https://doi.org/10.5194/gmd-5-1471-2012, 2012.

He, J., Wang, Y., Hao, J., Shen, L., and Wang, L.: Variations of surface $\mathrm{O}_{3}$ in August at a rural site near Shanghai: Influences from the West Pacific subtropical high and anthropogenic emissions, Environ. Sci. Pollut. Res., 19, 4016-4029, https://doi.org/10.1007/s11356-012-0970-5, 2012.

He, Y. J., Uno, I., Wang, Z. F., Pochanart, P., Li, J., and Akimoto, H.: Significant impact of the East Asia monsoon on ozone seasonal behavior in the boundary layer of Eastern China and the west Pacific region, Atmos. Chem. Phys., 8, 7543-7555, https://doi.org/10.5194/acp-8-7543-2008, 2008.

Hess, P. G. and Zbinden, R.: Stratospheric impact on tropospheric ozone variability and trends: 1990-2009, Atmos. Chem. Phys., 13, 649-674, https://doi.org/10.5194/acp-13-649-2013, 2013.

Holtslag, A. A. M. and Boville, B. A.: Local versus nonlocal boundary-layer diffusion in a global climate model, J. Clim., 6, 1825-1842, https://doi.org/10.1175/15200442(1993)006<1825:LVNBLD>2.0.CO;2, 1993.

Hudman, R. C., Moore, N. E., Mebust, A. K., Martin, R. V., Russell, A. R., Valin, L. C., and Cohen, R. C.: Steps towards a mechanistic model of global soil nitric oxide emissions: implementation and space based-constraints, Atmos. Chem. Phys., 12, 7779-7795, https://doi.org/10.5194/acp-12-7779-2012, 2012.

IPCC: Climate change 2013: The physical science basis, in: Contribution of Working Group I to the Fifth Assessment Report of the Intergovernmental Panel on Climate Change, edited by: Stocker, T. F., Qin, D., Plattner, G.-K., Tignor, M., Allen, S. K., Boschung, J., Nauels, A., Xia, Y., Bex, V., and Mildgley, P. M., Cambridge University Press, Cambridge, United Kingdom and New York, 1-1535, 2013.

Jacob, D. J., Logan, J. A., and Murti, P. P.: Effect of rising Asian emissions on surface ozone in the United States, Geophys. Res. Lett., 26, 2175-2178, https://doi.org/10.1029/1999GL900450, 1999.

Kuhns, H., Green, M., Etyemezian, V., Watson, J., and Pitchford, M.: Big Bend Regional Aerosol and Visibility Observational (BRAVO) Study Emissions Inventory, Report prepared for BRAVO Steering Committee, Desert Research Institute, Las Vegas, Nevada, 2003.

Kurokawa, J., Ohara, T., Morikawa, T., Hanayama, S., JanssensMaenhout, G., Fukui, T., Kawashima, K., and Akimoto, H.: Emissions of air pollutants and greenhouse gases over Asian re- gions during 2000-2008: Regional Emission inventory in ASia (REAS) version 2, Atmos. Chem. Phys., 13, 11019-11058, https://doi.org/10.5194/acp-13-11019-2013, 2013.

Li, J., Wang, Z., Akimoto, H., Gao, C., Pochanart, P., and Wang, X.: Modeling study of ozone seasonal cycle in lower troposphere over east Asia, J. Geophys. Res.-Atmos., 112, D22S25, https://doi.org/10.1029/2006JD008209, 2007.

Li, M., Liu, H., Geng, G., Hong, C., Liu, F., Song, Y., Tong, D., Zheng, B., Cui, H., Man, H., Zhang, Q., and He, K.: Anthropogenic emission inventories in China: A review, Natl. Sci. Rev., 4, 834-866, https://doi.org/10.1093/nsr/nwx150, 2017a.

Li, M., Zhang, Q., Kurokawa, J.-I., Woo, J.-H., He, K., Lu, Z., Ohara, T., Song, Y., Streets, D. G., Carmichael, G. R., Cheng, Y., Hong, C., Huo, H., Jiang, X., Kang, S., Liu, F., Su, H., and Zheng, B.: MIX: a mosaic Asian anthropogenic emission inventory under the international collaboration framework of the MICS-Asia and HTAP, Atmos. Chem. Phys., 17, 935-963, https://doi.org/10.5194/acp-17-935-2017, 2017 b.

Lin, J. T. and McElroy, M. B.: Impacts of boundary layer mixing on pollutant vertical profiles in the lower troposphere: Implications to satellite remote sensing, Atmos. Environ., 44, 17261739, https://doi.org/10.1016/j.atmosenv.2010.02.009, 2010.

Lin, J. T., Wuebbles, D. J., and Liang, X. Z.: Effects of intercontinental transport on surface ozone over the United States: Present and future assessment with a global model, Geophys. Res. Lett., 35, L02805, https://doi.org/10.1029/2007GL031415, 2008.

Lin, M., Holloway, T., Oki, T., Streets, D. G., and Richter, A.: Multiscale model analysis of boundary layer ozone over East Asia, Atmos. Chem. Phys., 9, 3277-3301, https://doi.org/10.5194/acp9-3277-2009, 2009

Lin, M., Fiore, A. M., Horowitz, L. W., Langford, A. O., Oltmans, S. J., Tarasick, D., and Rieder, H. E.: Climate variability modulates western US ozone air quality in spring via deep stratospheric intrusions, Nat. Commun., 6, 7105, https://doi.org/10.1038/ncomms8105, 2015.

Logan, J. A.: Tropospheric ozone: Seasonal behavior, trends, and anthropogenic influence, J. Geophys. Res.-Atmos., 90, 1046310482, https://doi.org/10.1029/JD090iD06p10463, 1985.

Lou, S., Liao, H., Yang, Y., and Mu, Q.: Simulation of the interannual variations of tropospheric ozone over China: Roles of variations in meteorological parameters and anthropogenic emissions, Atmos. Environ., 122, 839-851, https://doi.org/10.1016/j.atmosenv.2015.08.081, 2015.

Lu X., Hong J., Zhang L., Cooper OR.,Schultz MG., Xu X., Wang T., Gao M., Zhao Y., and Zhang Y., Environ. Sci. Technol. Lett., 5, 487-494, 2018.

Ma, Z., Xu, J., Quan, W., Zhang, Z., Lin, W., and Xu, X.: Significant increase of surface ozone at a rural site, north of eastern China, Atmos. Chem. Phys., 16, 3969-3977, https://doi.org/10.5194/acp-16-3969-2016, 2016.

Mao, J., Paulot, F., Jacob, D. J., Cohen, R. C., Crounse, J. D., Wennberg, P. O., Keller, C. A., Hudman, R. C., Barkley, M. P., and Horowitz, L. W.: Ozone and organic nitrates over the eastern United States: Sensitivity to isoprene chemistry, J. Geophys. Res.-Atmos., 118, 11256-11268, https://doi.org/10.1002/jgrd.50817, 2013.

McLinden, C. A., Olsen, S. C., Hannegan, B., Wild, O., Prather, M. J., and Sundet, J.: Stratospheric ozone in 3D models: A simple chemistry and the cross-tropopause 
flux, J. Geophys. Res.-Atmos., 105, 14653-14665, https://doi.org/10.1029/2000JD900124, 2000.

Meng, Z. Y., Xu, X. B., Yan, P., Ding, G. A., Tang, J., Lin, W. L., Xu, X. D., and Wang, S. F.: Characteristics of trace gaseous pollutants at a regional background station in Northern China, Atmos. Chem. Phys., 9, 927-936, https://doi.org/10.5194/acp-9927-2009, 2009.

Monks, P. S.: A review of the observations and origins of the spring ozone maximum, Atmos. Environ., 34, 3545-3561, https://doi.org/10.1016/S1352-2310(00)00129-1, 2000.

Monks, P. S., Archibald, A. T., Colette, A., Cooper, O., Coyle, M., Derwent, R., Fowler, D., Granier, C., Law, K. S., Mills, G. E., Stevenson, D. S., Tarasova, O., Thouret, V., von Schneidemesser, E., Sommariva, R., Wild, O., and Williams, M. L.: Tropospheric ozone and its precursors from the urban to the global scale from air quality to short-lived climate forcer, Atmos. Chem. Phys., 15, 8889-8973, https://doi.org/10.5194/acp-15-8889-2015, 2015.

Murray, L. T., Jacob, D. J., Logan, J. A., Hudman, R. C., and Koshak, W. J.: Optimized regional and interannual variability of lightning in a global chemical transport model constrained by LIS/OTD satellite data, J. Geophys. Res.-Atmos., 117, D20307 https://doi.org/10.1029/2012JD017934, 2012.

Ni, R., Lin, J., Yan, Y., and Lin, W.: Foreign and domestic contributions to springtime ozone over China, Atmos. Chem. Phys., 18, 11447-11469, https://doi.org/10.5194/acp-18-114472018, 2018.

Oltmans, S. J., Lefohn, A. S., Shadwick, D., Harris, J. M., Scheel, H. E., Galbally, I., Tarasick, D. W., Johnson, B. J., Brunke, E. G., Claude, H., Zeng, G., Nichol, S., Schmidlin, F., Davies, J., Cuevas, E., Redondas, A., Naoe, H., Nakano, T., and Kawasato, T.: Recent tropospheric ozone changes: A pattern dominated by slow or no growth, Atmos. Environ., 67, 331-351, https://doi.org/10.1016/j.atmosenv.2012.10.057, 2013.

Ott, L. E., Pickering, K. E., Stenchikov, G. L., Allen, D. J., DeCaria, A. J., Ridley, B., Lin, R. F., Lang, S., and Tao, W. K.: Production of lightning $\mathrm{NO}_{x}$ and its vertical distribution calculated from three-dimensional cloud-scale chemical transport model simulations, J. Geophys. Res.-Atmos., 115, D04301, https://doi.org/10.1029/2009JD011880, 2010.

Parrish, D., Lamarque, J. F., Naik, V., Horowitz, L., Shindell, D., Staehelin, J., Derwent, R., Cooper, O., Tanimoto, H., VolzThomas, A., Gilge, S., Scheel, H.-E., Steinbacher, M., and Fröhlich, M.: Long-term changes in lower tropospheric baseline ozone concentrations: Comparing chemistry-climate models and observations at northern midlatitudes, J. Geophys. Res.-Atmos., 119, 5719-5736, https://doi.org/10.1002/2013JD021435, 2014.

Price, C. and Rind, D.: A simple lightning parameterization for calculating global lightning distributions, J. Geophys. Res.-Atmos., 97, 9919-9933, https://doi.org/10.1029/92JD00719, 1992.

Ramsey, N. R., Klein, P. M., and Moore, B.: The impact of meteorological parameters on urban air quality, Atmos. Environ., 86, 58-67, https://doi.org/10.1016/j.atmosenv.2013.12.006, 2014.

Randerson, J., Chen, Y., Werf, G., Rogers, B., and Morton, D.: Global burned area and biomass burning emissions from small fires, J. Geophys. Res., 117, G04012, https://doi.org/10.1029/2012JG002128, 2012.

Real, E., Law, K. S., Weinzierl, B., Fiebig, M., Petzold, A., Wild, O., Methven, J., Arnold, S., Stohl, A., Huntrieser, H., Roiger, A., Schlager, H., Stewart, D., Avery, M., Sachse, G., Browell,
E., Ferrare, R., and Blake, D.: Processes influencing ozone levels in Alaskan forest fire plumes during long-range transport over the North Atlantic, J. Geophys. Res.-Atmos., 112, D10S41, https://doi.org/10.1029/2006JD007576, 2007.

Seinfeld, J. H. and Pandis, S. N.: Atmospheric Chemistry and Physics: From Air Pollution to Climate Change, John Wiley \& Sons, 2016.

Sun, L., Xue, L., Wang, T., Gao, J., Ding, A., Cooper, O. R., Lin, M., Xu, P., Wang, Z., Wang, X., Wen, L., Zhu, Y., Chen, T., Yang, L., Wang, Y., Chen, J., and Wang, W.: Significant increase of summertime ozone at Mount Tai in Central Eastern China, Atmos. Chem. Phys., 16, 10637-10650, https://doi.org/10.5194/acp-1610637-2016, 2016.

Verstraeten, W. W., Neu, J. L., Williams, J. E., Bowman, K. W., Worden, J. R., and Boersma, K. F.: Rapid increases in tropospheric ozone production and export from China, Nat. Geosci., 8, 690, https://doi.org/10.1038/ngeo2493, 2015.

Wang, T., Ding, A., Gao, J., and Wu, W. S.: Strong ozone production in urban plumes from Beijing, China, Geophys. Res. Lett., 33, L21806, https://doi.org/10.1029/2006GL027689, 2006.

Wang, T., Wei, X. L., Ding, A. J., Poon, C. N., Lam, K. S., Li, Y. S., Chan, L. Y., and Anson, M.: Increasing surface ozone concentrations in the background atmosphere of Southern China, 1994-2007, Atmos. Chem. Phys., 9, 6217-6227, https://doi.org/10.5194/acp-9-6217-2009, 2009.

Wang, T., Xue, L., Brimblecombe, P., Lam, Y. F., Li, L., and Zhang, L.: Ozone pollution in China: A review of concentrations, meteorological influences, chemical precursors, and effects, Sci. Total Environ., 575, 1582-1596, https://doi.org/10.1016/j.scitotenv.2016.10.081, 2017.

Wang, Y., Zhang, Y., Hao, J., and Luo, M.: Seasonal and spatial variability of surface ozone over China: contributions from background and domestic pollution, Atmos. Chem. Phys., 11, 35113525, https://doi.org/10.5194/acp-11-3511-2011, 2011.

Wild, O., Pochanart, P., and Akimoto, H.: Trans-Eurasian transport of ozone and its precursors, J. Geophys. Res.-Atmos., 109, D11302, https://doi.org/10.1029/2003JD004501, 2004.

Wu, J., Kong, S., Wu, F., Cheng, Y., Zheng, S., Yan, Q., Zheng, H., Yang, G., Zheng, M., Liu, D., Zhao, D., and Qi, S.: Estimating the open biomass burning emissions in central and eastern China from 2003 to 2015 based on satellite observation, Atmos. Chem. Phys., 18, 11623-11646, https://doi.org/10.5194/acp-18-116232018, 2018.

Xiao, Y., Logan, J. A., Jacob, D. J., Hudman, R. C., Yantosca, R., and Blake, D. R.: Global budget of ethane and regional constraints on US sources, J. Geophys. Res.-Atmos., 113, D21306, https://doi.org/10.1029/2007JD009415, 2008.

Xu, W., Lin, W., Xu, X., Tang, J., Huang, J., Wu, H., and Zhang, $\mathrm{X}$.: Long-term trends of surface ozone and its influencing factors at the Mt Waliguan GAW station, China - Part 1: Overall trends and characteristics, Atmos. Chem. Phys., 16, 6191-6205, https://doi.org/10.5194/acp-16-6191-2016, 2016.

Xu, W., Xu, X., Lin, M., Lin, W., Tarasick, D., Tang, J., Ma, J., and Zheng, X.: Long-term trends of surface ozone and its influencing factors at the Mt Waliguan GAW station, China - Part 2: The roles of anthropogenic emissions and climate variability, Atmos. Chem. Phys., 18, 773-798, https://doi.org/10.5194/acp-18-7732018, 2018. 
Xu, W. Y., Zhao, C. S., Ran, L., Deng, Z. Z., Liu, P. F., Ma, N., Lin, W. L., Xu, X. B., Yan, P., He, X., Yu, J., Liang, W. D., and Chen, L. L.: Characteristics of pollutants and their correlation to meteorological conditions at a suburban site in the North China Plain, Atmos. Chem. Phys., 11, 4353-4369, https://doi.org/10.5194/acp-11-4353-2011, 2011.

Xu, X., Lin, W., Wang, T., Yan, P., Tang, J., Meng, Z., and Wang, Y.: Long-term trend of surface ozone at a regional background station in eastern China 1991-2006: enhanced variability, Atmos. Chem. Phys., 8, 2595-2607, https://doi.org/10.5194/acp-8-25952008, 2008.

Xu, Z., Wang, T., Xue, L. K., Louie, P. K. K., Luk, C. W. Y., Gao, J., Wang, S. L., Chai, F. H., and Wang, W. X.: Evaluating the uncertainties of thermal catalytic conversion in measuring atmospheric nitrogen dioxide at four differently polluted sites in China, Atmos. Environ., 76, 221-226, https://doi.org/10.1016/j.atmosenv.2012.09.043, 2013.

Xue, L. K., Wang, T., Gao, J., Ding, A. J., Zhou, X. H., Blake, D. R., Wang, X. F., Saunders, S. M., Fan, S. J., Zuo, H. C., Zhang, Q. Z., and Wang, W. X.: Ground-level ozone in four Chinese cities: precursors, regional transport and heterogeneous processes, Atmos. Chem. Phys., 14, 13175-13188, https://doi.org/10.5194/acp-1413175-2014, 2014.

Yamaji, K., Li, J., Uno, I., Kanaya, Y., Irie, H., Takigawa, M., Komazaki, Y., Pochanart, P., Liu, Y., Tanimoto, H., Ohara, T., Yan, X., Wang, Z., and Akimoto, H.: Impact of open crop residual burning on air quality over Central Eastern China during the Mount Tai Experiment 2006 (MTX2006), Atmos. Chem. Phys., 10, 7353-7368, https://doi.org/10.5194/acp-107353-2010, 2010.

Yan, Y., Lin, J., and He, C.: Ozone trends over the United States at different times of day, Atmos. Chem. Phys., 18, 1185-1202, https://doi.org/10.5194/acp-18-1185-2018, 2018a.

Yan, Y., Pozzer, A., Ojha, N., Lin, J., and Lelieveld, J.: Analysis of European ozone trends in the period 1995-2014, Atmos. Chem. Phys., 18, 5589-5605, https://doi.org/10.5194/acp18-5589-2018, 2018b.

Yan, Y.-Y., Lin, J.-T., Kuang, Y., Yang, D., and Zhang, L.: Tropospheric carbon monoxide over the Pacific during HIPPO: two-way coupled simulation of GEOS-Chem and its multiple nested models, Atmos. Chem. Phys., 14, 12649-12663, https://doi.org/10.5194/acp-14-12649-2014, 2014.
Young, P. J., Archibald, A. T., Bowman, K. W., Lamarque, J.-F., Naik, V., Stevenson, D. S., Tilmes, S., Voulgarakis, A., Wild, O., Bergmann, D., Cameron-Smith, P., Cionni, I., Collins, W. J., Dalsøren, S. B., Doherty, R. M., Eyring, V., Faluvegi, G., Horowitz, L. W., Josse, B., Lee, Y. H., MacKenzie, I. A., Nagashima, T., Plummer, D. A., Righi, M., Rumbold, S. T., Skeie, R. B., Shindell, D. T., Strode, S. A., Sudo, K., Szopa, S., and Zeng, G.: Preindustrial to end 21 st century projections of tropospheric ozone from the Atmospheric Chemistry and Climate Model Intercomparison Project (ACCMIP), Atmos. Chem. Phys., 13, 2063 2090, https://doi.org/10.5194/acp-13-2063-2013, 2013.

Zhang, L., Jacob, D. J., Yue, X., Downey, N. V., Wood, D. A., and Blewitt, D.: Sources contributing to background surface ozone in the US Intermountain West, Atmos. Chem. Phys., 14, 52955309, https://doi.org/10.5194/acp-14-5295-2014, 2014a.

Zhang, Q., Yuan, B., Shao, M., Wang, X., Lu, S., Lu, K., Wang, M., Chen, L., Chang, C.-C., and Liu, S. C.: Variations of ground-level $\mathrm{O}_{3}$ and its precursors in Beijing in summertime between 2005 and 2011, Atmos. Chem. Phys., 14, 6089-6101, https://doi.org/10.5194/acp-14-6089-2014, 2014b.

Zhao, C., Wang, Y., and Zeng, T.: East China Plains: A 'basin' of ozone pollution, Environ. Sci. Technol., 43, 1911-1915, https://doi.org/10.1021/es8027764, 2009.

Zhao, C., Wang, Y., Yang, Q., Fu, R., Cunnold, D., and Choi, Y.: Impact of East Asian summer monsoon on the air quality over China: View from space, J. Geophys. Res.-Atmos., 115, D09301, https://doi.org/10.1029/2009JD012745, 2010.

Zheng, B., Tong, D., Li, M., Liu, F., Hong, C., Geng, G., Li, H., Li, X., Peng, L., Qi, J., Yan, L., Zhang, Y., Zhao, H., Zheng, Y., He, K., and Zhang, Q.: Trends in China's anthropogenic emissions since 2010 as the consequence of clean air actions, Atmos. Chem. Phys., 18, 14095-14111, https://doi.org/10.5194/acp-18-140952018, 2018. 